\title{
GNSS and RPAS integration techniques for studying landslide dynamics: Application to the areas of Victoria and Colinas Lojanas, (Loja, Ecuador)
}

\author{
Belizario A. Zárate Torres ${ }^{1}$, Rachid El Hamdouni ${ }^{2}$, Tomas Fernández del Castillo ${ }^{3}$
}

$5{ }^{1}$ Departament of Geology, Mines and Civil Engineer, Private Technical University of Loja, Loja, AP. 1101608, Ecuador. ${ }^{2}$ Department of Civil Engineering, ETSICCP, University of Granada, Spain, Campus Fuentenueva s/n, Granada 18071, Spain. ${ }^{3}$ Department of Geology, University of Jaén, Campus de las Lagunillas s/n, 23071 Jaén, 23071, Spain.

Correspondence to: Belizario A. Zárate Torres (bazarate@utpl.edu.ec)

10 Abstract. This research tests the application of GNSS and RPAS techniques to the spatiotemporal analysis of landslide dynamics. Our method began by establishing non-permanent GNSS networks on the slope surfaces to perform periodic measurements by differential GNSS. Similarly, RPAS flights were made to acquire high-resolution images, which were oriented and georeferenced using ground control points and structure-from-motion algorithms to obtain digital surface models and orthophotos ultimately. Based on GNSS measurements, the direction and velocity of displacements were accurately

15 calculated, and orthophotos and DSMs were used to calculate horizontal and vertical displacements in a set of significant points throughout the study area, reaching accuracies higher than $0.035 \mathrm{~m}$ in the GNSS data and $0.10 \mathrm{~m}$ in the RPAS data. These values were within the accuracy required for such studies. Based on the field observations and the results from the photogrammetric studies, the two studied landslides were classified as very slow flows.

\section{Introduction}

20 Landslides are natural processes that cause economic and human losses worldwide (Agüera-Vega et al., 2018; Assilzadeh et al., 2010; Donnini et al., 2017), especially when events, such as specific types of flows, occur in a short time (Psimoulis et al., 2018). Many authors have studied how to reduce the risk impact of landslides (Choi and Cheung, 2013; Fernández et al., 2013; Kumar and Anbalagan, 2015; Lari et al., 2014; Ponomarev et al., 2017). Since 1990, global navigation satellite systems (GNSSs) have been frequently used to monitor landslides (Bellone et al., 2016; Capilla et al., 2016; Li and Wang, 2011; Malet et al., 1994), enabling researchers to determine landslide kinematics (Hastaoglu and Sanli, 2011; Rawat et al., 2011). GNSS surveys are usually carried out with a given frequency ( i.e. monthly, weekly) and results are discontinuous over time, and related to the cumulative movements of surface points. Recent advances in remote sensing have made it possible to collect $3 \mathrm{D}$ data of the terrain, which have been used in landslide research (Jaboyedoff et al., 2012; Metternicht et al., 2005), including in the techniques interferometric synthetic aperture radar (InSAR), differential interferometric synthetic aperture radar (DInSAR), light detection and ranging (LIDAR), and photogrammetry. The airborne LIDAR technique (ALS) and the terrestrial LIDAR 
https://doi.org/10.5194/nhess-2021-32

Natural Hazards

Preprint. Discussion started: 8 February 2021

(c) Author(s) 2021. CC BY 4.0 License.

technique (TLS) generate a point cloud, which makes it possible to interpolate high-resolution digital terrain models with submetre accuracy (Hsieh et al., 2016; Medjkane et al., 2018). The high accuracy of these models has enabled their use in landslide mapping and monitoring (Cavalli and Marchi, 2008; Dewitte et al., 2008; Fernández et al., 2017; Gaprindashvili and Van Westen, 2016; Irigaray and Palenzuela, 2013; Jaboyedoff et al., 2012; Johnson et al., 2014; Kasai et al., 2009; McKean and

35 Roering, 2004; Růžičková and Inspektor, 2015; Tiwari et al., 2018).

Airborne photogrammetry has also been frequently used in landslide studies to analyse both individual ground movements and wider regions (ASPRS, 1990; Boccardo et al., 2015; Chen et al., 2018; Dewitte et al., 2008; Fernández et al., 2013, 2017; Kasperski et al., 2010; Mozas-Calvache et al., 2017; Prokešová et al., 2010; Walstra et al., 2004). In these studies, after block orientation based on conventional techniques of aerial triangulation and block adjustment, digital terrain models (DTMs) or digital surface models (DSMs) are calculated using automatic correlation techniques. From these models, in all studies, a DSM/DTM of differences (DoD) is interpolated, or volumetric calculations are made, and some have calculated the 3D displacement vectors (Walstra et al., 2004).

Currently, remotely piloted aircraft systems (RPASs) or also known as unmanned aerial vehicles (UAVs) when referring only to the vehicle, equipped with metric and non-metric digital cameras (Stumpf et al., 2015), are highly valid and low-cost

45 alternatives to conventional photogrammetric flights for the development of very high-resolution applications. These applications have been stimulated by the enhanced performance of these systems and by the use of new computer vision algorithms, particularly structure from motion (SfM), which is applied for the orientation of photogrammetric blocks, and multiple-view stereo (MVS), which is applied for the interpolation of DSM/DTM by point-cloud densification (Eltner et al., 2016; Seitz et al., 2006). These processes, which involve using specific software (Agisoft, 2018; González-Aguilera et al.,

50 2016; Pix4D, 2017), results in orthophotos. Both DTM and DSM are used for the geomorphic characterisation of landslides and their characteristics (Al-Rawabdeh et al., 2016; Fernández et al., 2015; Niethammer et al., 2012; Peppa et al., 2016; Stumpf et al., 2013), or more frequently for interpolating differential models to identify changes in the ground surface, volumetric calculations, and profiles (Fernández et al., 2015; Lindner et al., 2016; Mozas-Calvache et al., 2016; Niethammer et al., 2012; Peppa et al., 2016, 2019; Peternel et al., 2017; Rossi et al., 2018; Stumpf et al., 2013; Turner et al., 2015; Warrick et al., 2019).

55 In turn, orthophotos also enable landslides to be characterised and described, in particular by the precise calculation of horizontal displacements between significant points (Fernández et al., 2015, 2016; Lindner et al., 2016; Mozas-Calvache et al., 2017; Niethammer et al., 2012; Peternel et al., 2017; Rossi et al., 2018; Stumpf et al., 2013; Turner et al., 2015; Warrick et al., 2019).

This article addresses the use of the GNSS and RPAS techniques for high-accuracy field data collection. The case study is a

60 temporal analysis of two landslides that affected the Victoria and Colinas Lojanas sector of the city of Loja, Ecuador. By differential GNSS, a surface control was performed to calculate the landslide velocity. To support these efforts, RPAS techniques were integrated for image acquisition, which made it possible to generate a DSM and to temporarily assess its behaviour after post-processing. 
https://doi.org/10.5194/nhess-2021-32

Preprint. Discussion started: 8 February 2021

(c) Author(s) 2021. CC BY 4.0 License.

\section{Study areas}

65 The present research encompasses two study areas (Figure. 1). Both are located near the city of Loja, in southern Ecuador, in the sectors named Victoria and Colinas Lojanas. The climate is humid subtropical with an average annual precipitation of 917 $\mathrm{mm}$, although the rainfall is concentrated from December to April.

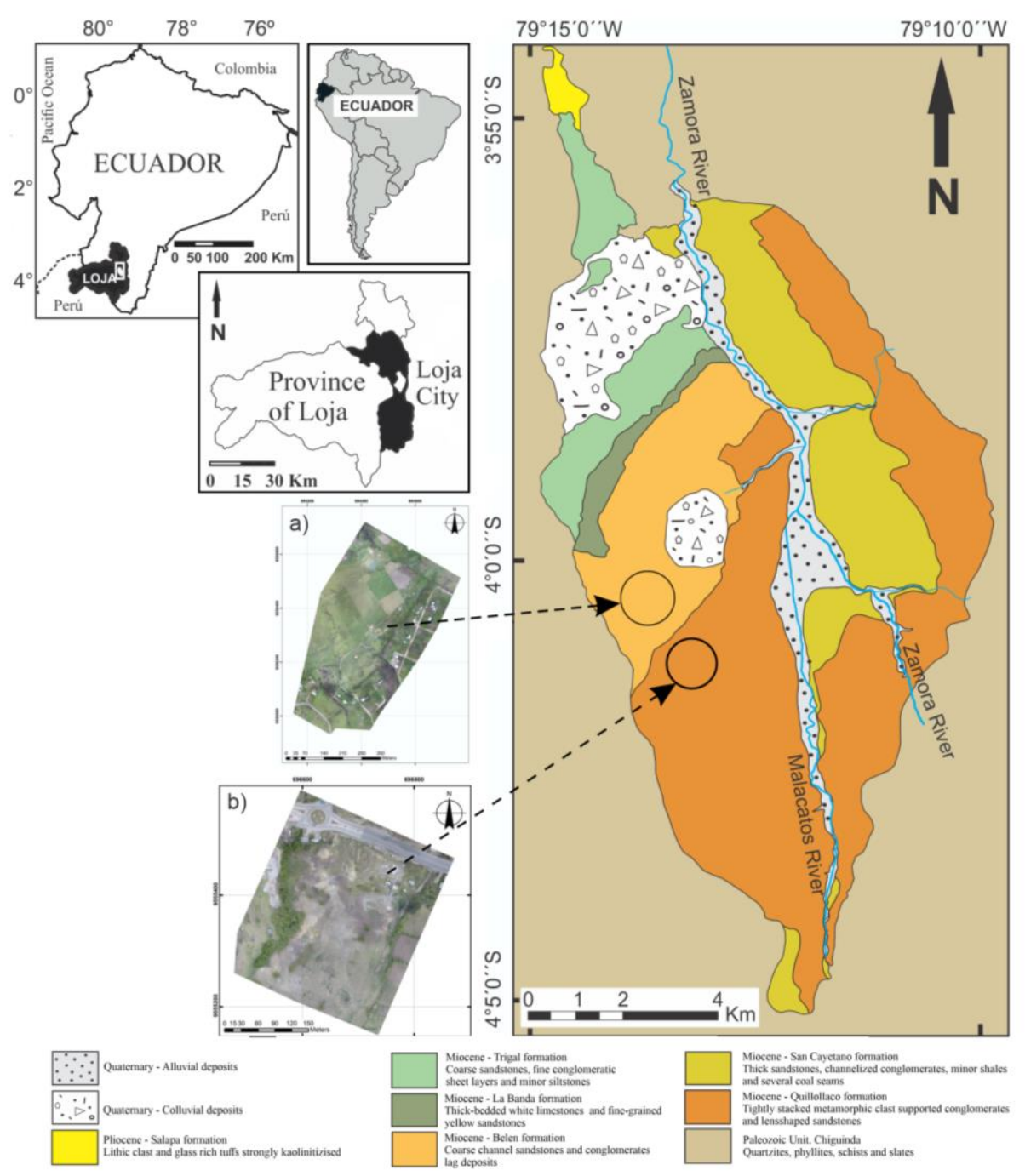

Figure 1. Locations and geological frameworks of the study areas. a) Victoria and b) Colinas Lojanas. Adapted from (Soto et al., 2017)

Geologically, the Loja basin is a Miocene-Pliocene lacustrine sedimentary unit filled on a basement of metamorphic rocks: Palaeozoic, impure, fine- to medium-grain quartzites, black phyllites, slates, and schists (some graphitic) (Figure 1) (Hungerbühler et al., 2002). 
https://doi.org/10.5194/nhess-2021-32

Preprint. Discussion started: 8 February 2021

(c) Author(s) 2021. CC BY 4.0 License.

(c) (1)

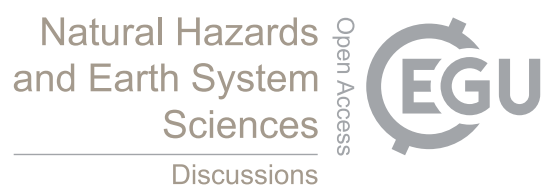

The Victoria sector is found in the Belén Formation (Miocene) and lithologically consists of thick-to-thin layers of sandstones

75 with conglomerate lenses and, to a lesser extent, layers of lutites deposited with colluvial material. The formation setting is mixed fluvial-deltaic (Hungerbühler et al., 2002). The landslide area is dominated by sands and clays caused by the weathering of pre-existing lithologies. The soil is highly saturated because this agricultural area is subjected to continuous irrigation in addition to the effects of rainfall. The predominant vegetation cover in the study area is grasses, with some isolated bushes. The existing types of cover on landslide areas include cliffs, roads, buildings, and bare soil. The landslide surface area is 21,860

$80 \mathrm{~m}^{2}$, and a $13.6 \%$ mean slope. Numerous several-metre-long tension cracks can be found running parallel to the crown of the landslide, highlighting the landslide activity. Figure 2 shows images of the landslide surface in Victoria. There are signs of deformation, such as scarps and cracks (with widths of $0.20 \mathrm{~m}$, lengths greater than $2 \mathrm{~m}$ and depths over $0.50 \mathrm{~m}$ ). 
https://doi.org/10.5194/nhess-2021-32

Preprint. Discussion started: 8 February 2021

(c) Author(s) 2021. CC BY 4.0 License.
Natural Hazards 웅 and Earth System Sciences

Discussions

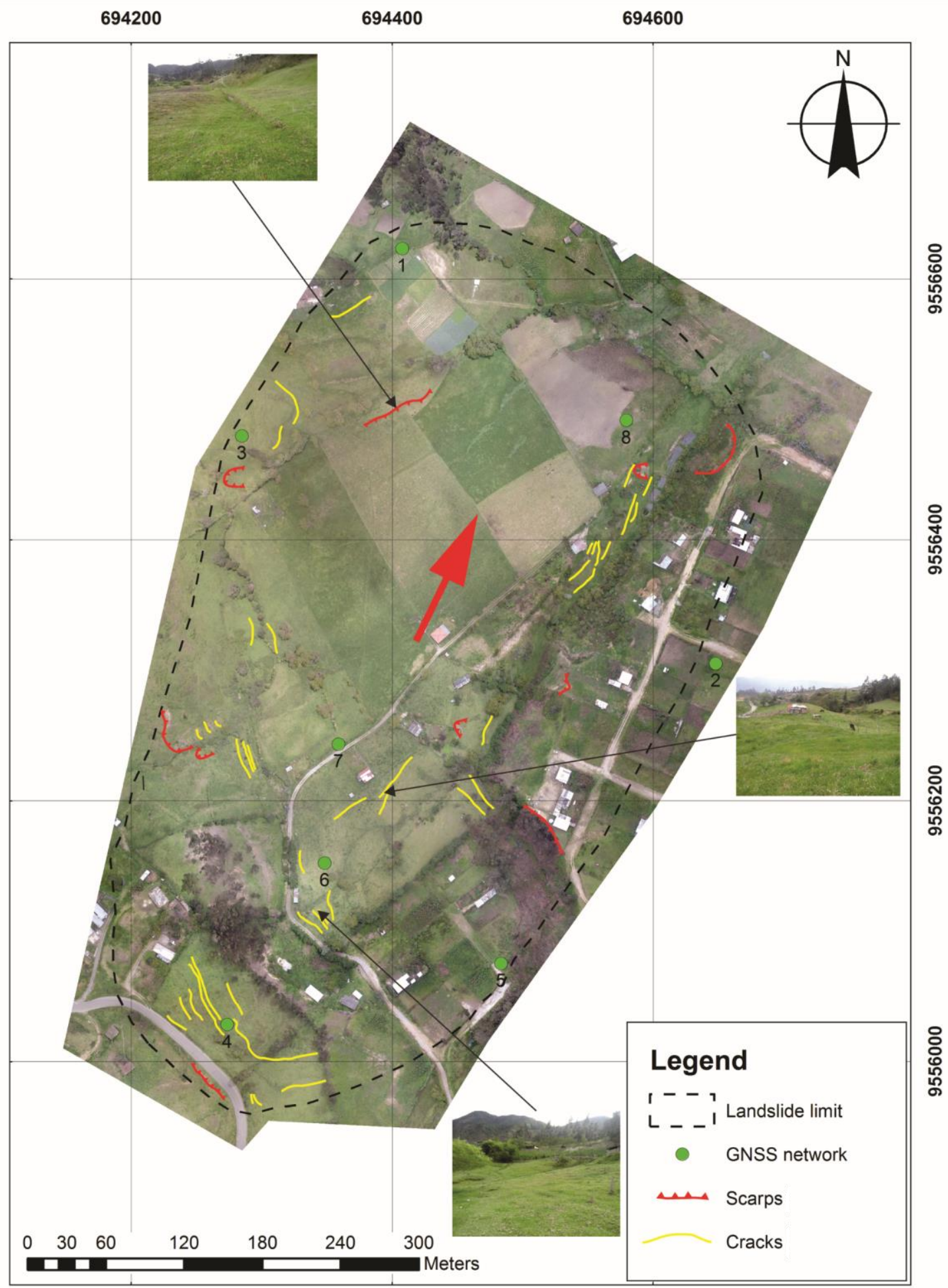


https://doi.org/10.5194/nhess-2021-32

Preprint. Discussion started: 8 February 2021

(c) Author(s) 2021. CC BY 4.0 License.

(c) (1)

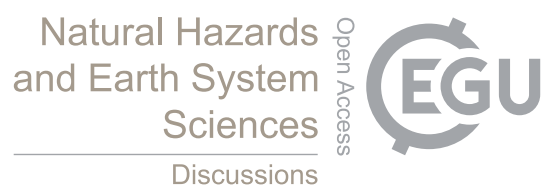

Figure 2. Geomorphological evidence of the landslide in the Victoria sector (Photograph February 2016). Images generated in Agisoft 85 PhotoScan and processed in ArcGIS.

The Colinas Lojanas sector is located on the Quillollaco Formation, which has four lithologies: conglomerates, clays, sands, and limonites. The conglomerates are the predominant rocks in the Quillollaco Formation that outcrop in natural and anthropic slopes. These conglomerates show sub-rounded clasts, primarily quartz, up to $15 \mathrm{~cm}$ in size, cemented in a sandy-silty matrix, with colours ranging from yellowish brown to light grey. The unstable zone covers an area of $65,845 \mathrm{~m}^{2}$, with an average slope

90 of $11 \%$. The presence of cracks, scarps, collapsed buildings, and affected road infrastructure is the main evidence of active ground movement, as shown in Fig. 3. 
https://doi.org/10.5194/nhess-2021-32

Preprint. Discussion started: 8 February 2021

(c) Author(s) 2021. CC BY 4.0 License.

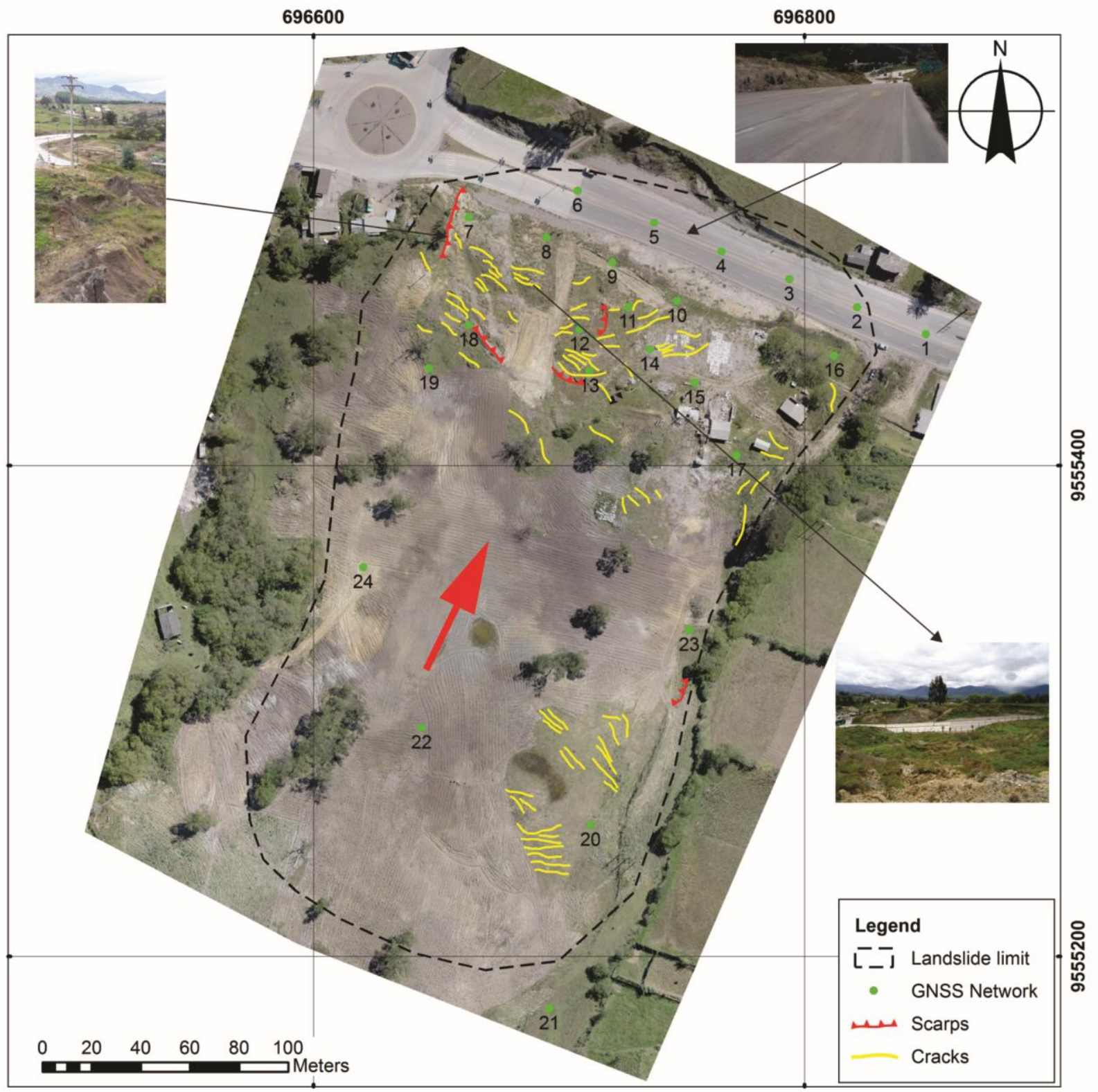

Figure 3. Geomorphological evidence in the Colinas Lojanas sector (July 2016) showing cracks distributed within the landslide body and the main scarps. The photograph of the road clearly shows the deformation produced at the foot of the landslide and affected buildings. Image generated in Agisoft PhotoScan and processed in ArcGIS 


\section{Material and methods}

\subsection{GNSS measurements and processing}

Two non-permanent GNSS control networks (Wang, 2013) were established in the study area. The first network, established in the Victoria sector, consisted of eight points, and the second network was installed in Colinas Lojanas with 24 points. These points consisted of concrete boundary markers with a $0.50 \mathrm{~m}$ long reinforcing steel rod at the centre and a tapered bore $3 \mathrm{~mm}$ in diameter at the free end to mount the GNSS receiver on a range pole. The differential GNSS technique (Fast Static) (Akbarimehr et al., 2013; Pesci et al., 2013; Rawat et al., 2011) was used to monitor the network using a Trimble R6 dualfrequency GNSS receiver (rover) (Figure. 4a) with a 10 minute occupation time, 1 second recording time, and $10^{\circ}$ elevation mask. This technique establishes accuracies of $5 \mathrm{~mm}$ with a measurement time between 8 to 20 minutes (Gili et al., 2000). To ensure the accuracy of the GNSS data recording, the verticality of the range pole on the point was assessed by checking the circular level.

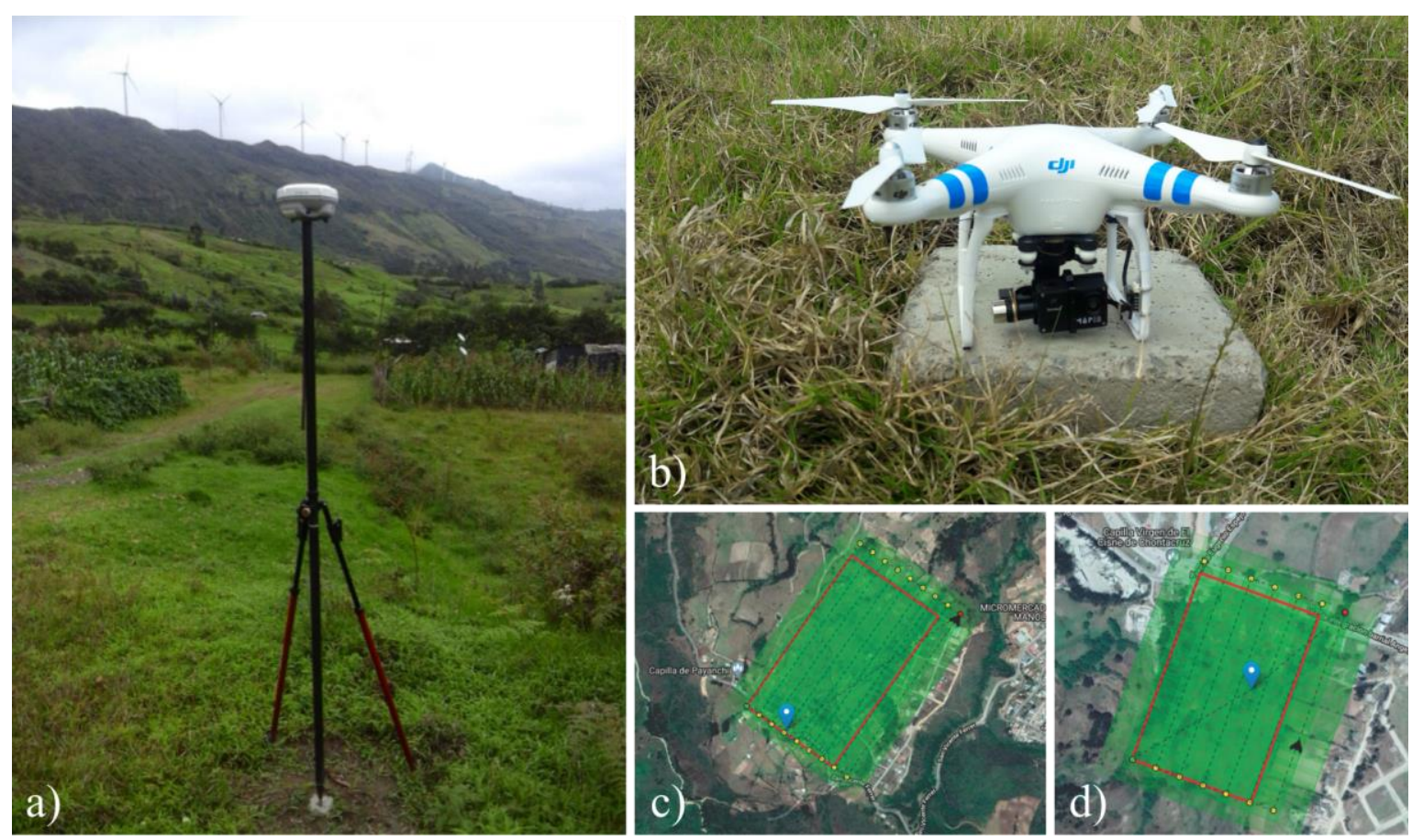

Figure 4. a) Trimble GNSS receiver model R6 used for the measurements on the control network. b) Phantom 2 drone equipped with a ventral camera. c) and d) Flight path planning in the Victoria and Colinas Lojanas sectors, respectively. Image a) and b) obtained by the authors, c) and d) obtained from Maps Made Easy website (www.mapsmadeeasy.com).

The downloaded data were postprocessed using the software Trimble Business Centre V 2. The accuracy of these points was $0.03 \mathrm{~m}$ for horizontal positions and $0.035 \mathrm{~m}$ for vertical measurements (Zárate, 2011). The GNSS antenna, termed LJEC, which belonged to the Ecuadorian network of the Geocentric Reference System for the Americas (SIRGAS), was used as the 
reference base station. The coordinate system used was WGS84-UTM 17S. Measurement campaigns with differential GNSSs were programmed for each sector, as outlined in Table 1.

Table 1. Detail of the GNSS measurement campaigns performed in the study areas. The time spans refer to the cumulative time between measurement campaigns.

\begin{tabular}{llll}
\hline Sector & Campaign & Measurement date & Cumulative time span (days) \\
\hline & 1 & 18 January 2016 & 1 \\
Victoria & 2 & 18 February 2016 & 32 \\
& 3 & 10 March 2016 & 53 \\
& 4 & 23 March 2016 & 66 \\
& 5 & 21 May 2016 & 125 \\
& 6 & 11 June 2016 & $\mathbf{1 4 6}$ \\
Colinas Lojanas & 1 & 22 August 2016 & 1 \\
& 2 & 6 September 2016 & 16 \\
& 4 & 29 September 2016 & 36 \\
& 5 & 13 October 2016 & 53 \\
& 6 & 28 October 2016 & 68 \\
& & 23 November 2016 & $\mathbf{9 4}$ \\
\hline
\end{tabular}

\subsection{RPAS values, orientation, and data collection}

To complement the GNSS measurement campaigns, two RPAS flights were made in the Victoria sector (18 February 2016 and 11 June 2016) and three flights in Colinas Lojanas (4 July 2016, 29 November 2016, and 12 January 2018). The flights in Victoria were made on the same day as the GNSS measurements were taken, in contrast to Colinas Lojanas, where the flights were made independently of the GNSS measurements. The flights were made with a DJI Phantom 2 drone (Fig. 4b) operating at flight heights of $50 \mathrm{~m}$ to $120 \mathrm{~m}$. Flight time was 20 minutes using a smart battery with a capacity of $5200 \mathrm{mAh}$. The (obstaclefree) range was $1000 \mathrm{~m}$. The elevation of the terrain was assessed to determine the highest and lowest topographic points (including the heights of structures and trees) to avoid collisions of the vehicle during the flight and to ensure a uniform resolution of the captured images that would be suitable for the study objectives. Rain and wind (Car et al., 2016) were the factors analysed before preparing the flight schedule due to their negative impact on electronic components, image quality,

130 and UAV safety. The optimal weather conditions (Hackney and Clayton, 2015; Mozas-Calvache et al., 2012; Uysal et al., 2015) for landslide evaluation are cloudy skies without rain and without wind; however, flights can be made with winds of 8 $\mathrm{km} \mathrm{h}^{-1}$. The flights were planned using the photogrammetric software GroundStation v 4.0.11 and the web application www.mapsmadeeasy.com. These applications make it possible to define the flight path, flight height, and forward and side 
https://doi.org/10.5194/nhess-2021-32

Preprint. Discussion started: 8 February 2021

(C) Author(s) 2021. CC BY 4.0 License.

overlaps in the study area, as shown in Fig. 4c and d. Table 2 outlines the design parameters of the RPAS flight paths in the

135 two study areas.

Table 2. Design parameters used to generate the flight paths in the study areas.

\begin{tabular}{|c|c|c|c|c|c|}
\hline Area & Victoria & & Colinas Loj & nas & \\
\hline Date & $\begin{array}{ll}18 & \text { February } \\
2016 & \end{array}$ & $\begin{array}{ll}11 & \text { June } \\
2016 & \end{array}$ & $\begin{array}{ll}4 & \text { July } \\
2016 & \end{array}$ & $\begin{array}{l}29 \quad \text { November } \\
2016\end{array}$ & $\begin{array}{ll}12 & \text { January } \\
2018 & \end{array}$ \\
\hline No. of images acquired & 243 & 268 & 216 & 221 & 208 \\
\hline No. of images used & 226 & 246 & 188 & 190 & 186 \\
\hline Forward overlap & $70 \%$ & $70 \%$ & $70 \%$ & $70 \%$ & $70 \%$ \\
\hline Side overlap & $60 \%$ & $60 \%$ & $60 \%$ & $60 \%$ & $60 \%$ \\
\hline Flight height & $120 \mathrm{~m}$ & $119 \mathrm{~m}$ & $97.4 \mathrm{~m}$ & $77.3 \mathrm{~m}$ & $92.2 \mathrm{~m}$ \\
\hline Number of flyovers & 14 & 14 & 12 & 12 & 12 \\
\hline North alignment & $35^{\circ}$ & $35^{\circ}$ & $20^{\circ}$ & $20^{\circ}$ & $20^{\circ}$ \\
\hline Photographic resolution ( $\mathrm{px}$ ) & $1.74 \times 1.74$ & $1.74 \times 1.74$ & $1.74 \times 1.74$ & $1.74 \times 1.74$ & $1.74 \times 1.74$ \\
\hline
\end{tabular}

Images were acquired using a GoPro 3+ Silver Edition 10-megapixel digital camera with $2.77 \mathrm{~mm}$ focal distance and $2624 \times 1968$ px resolution. The camera was set to acquire images at a constant interval of $2 \mathrm{~s}$.

140 For block orientation and subsequent DSM interpolation and orthophoto processing, the software Agisoft PhotoScan was used. The workflow began with image alignment and georeferencing using dense matching and SfM techniques, involving the automatic measurement of thousands of common waypoints between photographs. Next, the DSM was generated by pointcloud densification and orthophotos, creating textured digital 3D models where appropriate (Yucel and Turan, 2016). For flight orientation and georeferencing, five ground control points (GCPs) were used in the Victoria sector and six GCPs in the Colinas

145 Lojana sector, which are part of the GNSS control networks. The coordinate system used was WGS84-UTM 17S. The coordinates of these control points were determined with Trimble R6 dual-frequency GNSS in differential mode. The accuracies obtained in the orientation process, expressed as root-mean-square error (RMSE) in both GCPs and checkpoints (three in the Victoria sector and four in Colinas Lojanas), are outlined in Table 3. Thus, the horizontal errors (XY) of both control points and checkpoints ranged from 0.025 to $0.056 \mathrm{~m}$; vertical errors varied usually within the range $0.024-0.059 \mathrm{~m}$,

150 and in any case they were below $0.10 \mathrm{~m}$. These accuracies, both horizontal and vertical, were within the ranges established by the American Society for Photogrammetry and Remote Sensing (Agüera-Vega et al., 2017). 
https://doi.org/10.5194/nhess-2021-32

Preprint. Discussion started: 8 February 2021

(c) Author(s) 2021. CC BY 4.0 License.

Table 3. Accuracies assessed after processing the images acquired with an UAV by SfM in the two measurement periods.

\begin{tabular}{|c|c|c|c|c|c|c|}
\hline \multirow{3}{*}{ Processing results } & \multicolumn{2}{|l|}{ Victoria } & \multicolumn{4}{|c|}{ Colinas Lojanas } \\
\hline & February & 11 June 2016 & 4 July 2016 & $29 \quad$ November & 12 & January \\
\hline & 2016 & & & 2016 & 2018 & \\
\hline $\begin{array}{l}\text { Number of processed } \\
\text { images }\end{array}$ & 226 & 246 & 289 & 285 & 278 & \\
\hline Number of GCPs & 5 & 5 & 6 & 6 & 6 & \\
\hline $\mathrm{XY}$ error $(\mathrm{m})$ & 0.025 & 0.053 & 0.056 & 0.038 & 0.028 & \\
\hline Z error (m) & 0.038 & 0.024 & 0.040 & 0.059 & 0.103 & \\
\hline Total RMSE $(\mathrm{cm})$ & 0.045 & 0.053 & 0.069 & 0.070 & 0.030 & \\
\hline Number of checkpoints & 3 & 3 & 4 & 4 & 4 & \\
\hline $\mathrm{XY}$ error $(\mathrm{cm})$ & 0.026 & 0.056 & 0.039 & 0.026 & 0.026 & \\
\hline$Z$ error $(\mathrm{cm})$ & 0.041 & 0.042 & 0.061 & 0.041 & 0.039 & \\
\hline Total RMSE $(\mathrm{cm})$ & 0.049 & 0.070 & 0.073 & 0.049 & 0.047 & \\
\hline $\begin{array}{l}\text { Ground simple distance } \\
(\mathrm{GSD})\left(\mathrm{m} \mathrm{px}^{-1}\right)\end{array}$ & 0.060 & 0.060 & 0.070 & 0.070 & 0.070 & \\
\hline
\end{tabular}

In turn, the DSMs and orthophotos were exported as images, both with $0.05 \mathrm{~m}$ resolution. Figure 5 shows the orthophotos and DSMs generated for the Victoria sector, and Fig. 6 shows the orthophotos and DSM generated for the Colinas Lojanas sector, 160 according to the flights detailed in Table 2. 
https://doi.org/10.5194/nhess-2021-32

Preprint. Discussion started: 8 February 2021

(c) Author(s) 2021. CC BY 4.0 License.
Natural Hazards 웅 and Earth System Sciences
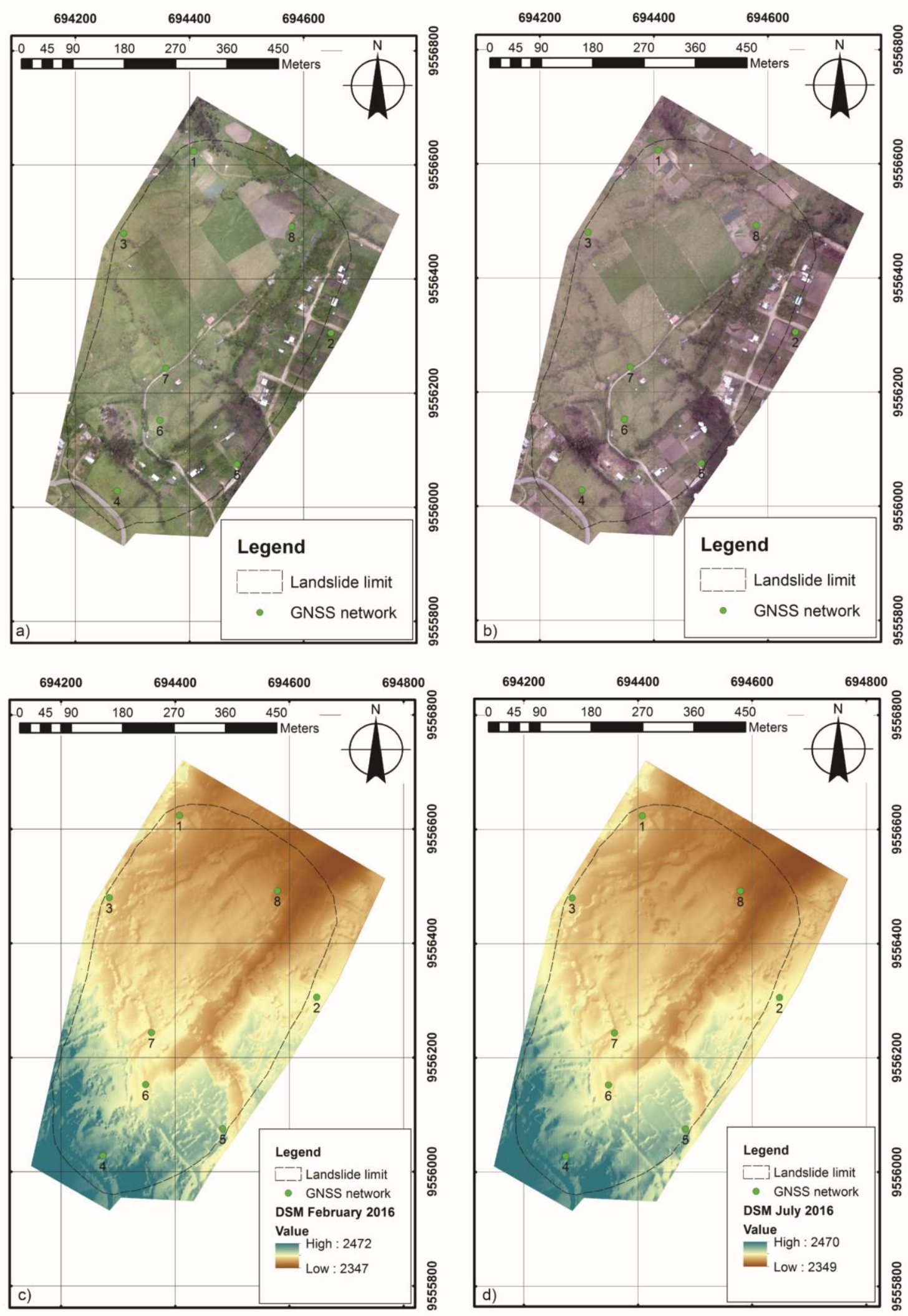
https://doi.org/10.5194/nhess-2021-32

Preprint. Discussion started: 8 February 2021

(c) Author(s) 2021. CC BY 4.0 License.

(c) (i)

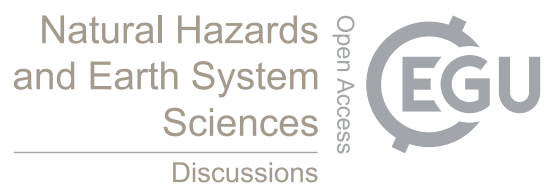

Figure 5. Orthophotos and DSMs of the Victoria sector generated by RPAS flights: a) and c) 18 February 2016 ; b) and d) 11 June

2016. Images generated in Agisoft PhotoScan and processed in ArcGIS. 
https://doi.org/10.5194/nhess-2021-32

Preprint. Discussion started: 8 February 2021

(c) Author(s) 2021. CC BY 4.0 License.
Natural Hazards 웅 and Earth System Sciences
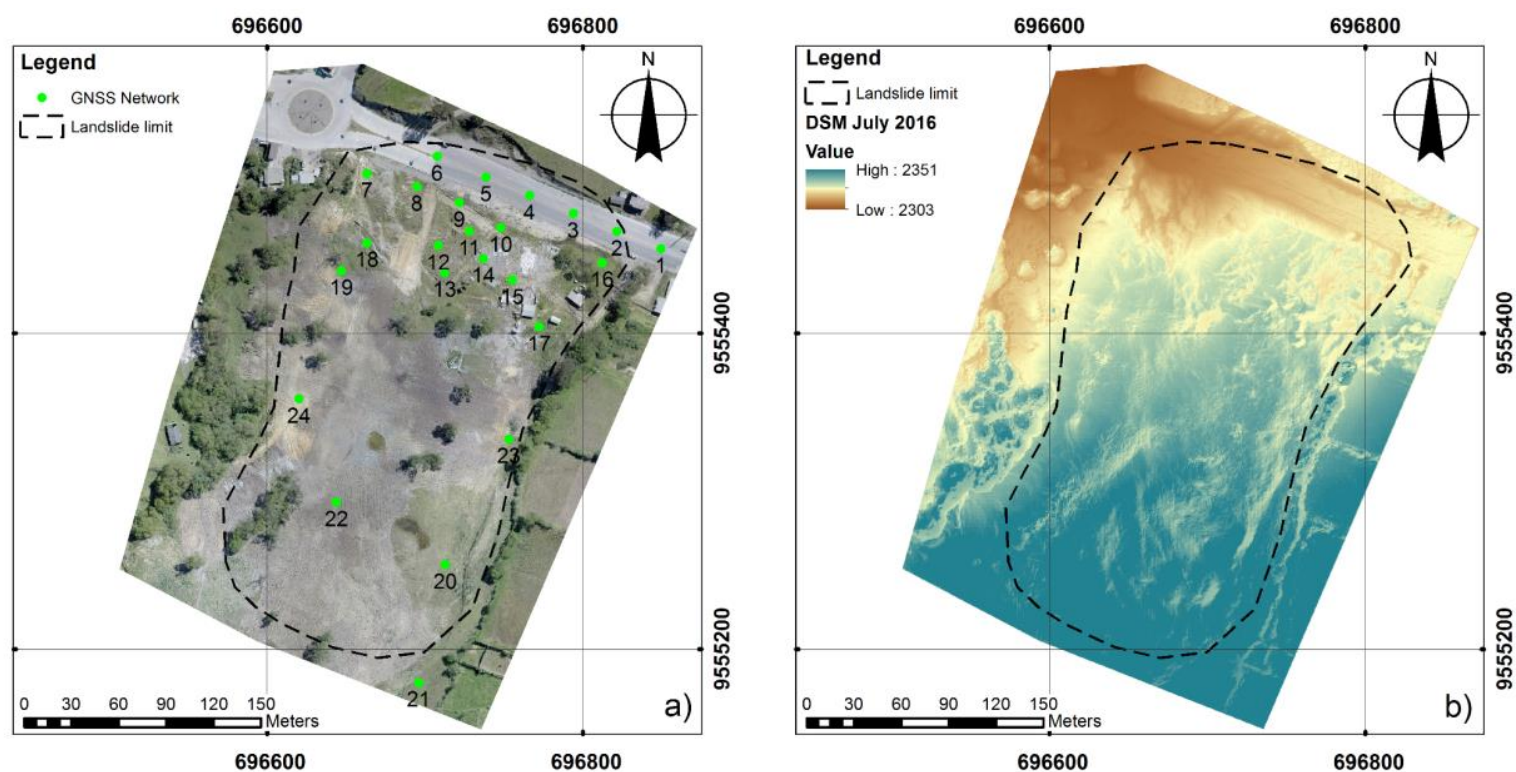

亳

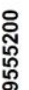
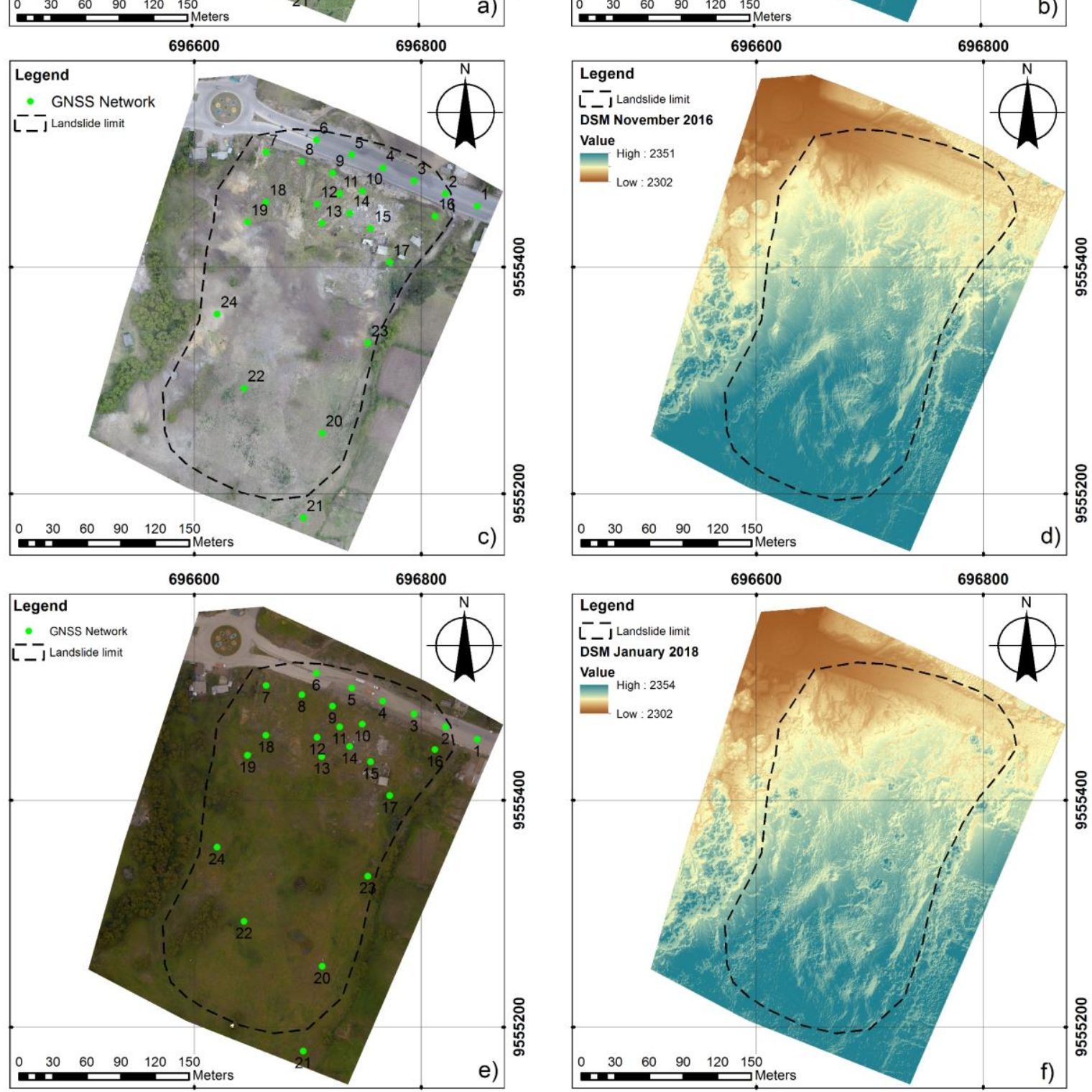
https://doi.org/10.5194/nhess-2021-32

Natural Hazards

Preprint. Discussion started: 8 February 2021

(c) Author(s) 2021. CC BY 4.0 License. November 2016; and e) and f) 12 January 2018. Images generated in Agisoft PhotoScan and processed in ArcGIS

\subsection{Displacement measurements}

In the case of GNSS networks, the displacements between each pair of campaigns are easily measured by subtracting the coordinates of the points of each campaign from those of the next campaign. Thus, the total displacements throughout the entire monitoring period were calculated by subtracting the initial coordinates (first campaign) from the final coordinates (last campaign). Thus, positive values indicated eastward, northward, and upward displacements, and negative values indicated westward, southward, and downward displacements.

In RPAS images, two types of approximations were made to measure changes in the terrain surface: calculating displacements between monitoring points and calculating differential models. The former consisted of calculating displacements in a series of significant monitoring points extracted from orthophotos and DSM. The monitoring points were manually located using the first orthophotos in the stable and unstable areas to put them as much as possible in bare soil without vegetation. The displacements calculated in the stable zone served to evaluate the accuracies and uncertainties of the images and calculations in the unstable zone to analyse the kinematics of the movements. This network of checkpoints was created and stored as a point layer in ArcGIS and was based on the WGS84-UTM 17S coordinate system.

180 The latter consisted of calculating DoD, which showed areas with vertical, and even horizontal, changes in the terrain surface. For this purpose, the corresponding tool of the ArcGIS software was used, adjusting the elevation ranges and eliminating values higher than $3 \mathrm{~m}$, which made it possible to saturate the colour palette at lower values and to detect subtle movements.

\section{Results}

\subsection{Displacements in control points measured by GNSS}

185 The time interval between GNSS monitoring campaigns was 94 days (3.13 months) for Victoria and 104 days (4.87 months) for Colinas Lojanas. Table 4 outlines the effective displacements, direction, and velocity of the points of the GNSS network established in Victoria. Velocity $\left(\mathrm{V}_{\mathrm{H}}\right)$ was assessed by comparing the resulting displacement vector $\left(\mathrm{D}_{\mathrm{NE}}\right)$ and the corresponding monitoring time. The analysis of displacement components of control points showed a predominantly northward (N) direction, especially at points 4, 5, 6, 7, and 8, with displacement ranging from $0.118 \mathrm{~m}$ to $0.212 \mathrm{~m}$. Points 1,2 , and 3

190 showed an eastward (E) trend, with values lower than $0.10 \mathrm{~m}$. Points 4, 5, 6, 7, and 8 were located within the zone of depletion, from the head to the foot, with higher displacements towards the top $(0.216 \mathrm{~m})$ and lower displacements at the toe $(0.056 \mathrm{~m})$. In turn, the other points were located on the west (W) (1 and 2) or east flanks (3), although the latter point was outside the landslide boundary. In all cases, the total horizontal displacements widely exceeded at all points the threshold defined by the accuracy of the instruments and GPS positioning method used $(0.03 \mathrm{~m}+1 \mathrm{ppm})$ and therefore could be considered significant. 
https://doi.org/10.5194/nhess-2021-32

Preprint. Discussion started: 8 February 2021

(C) Author(s) 2021. CC BY 4.0 License.

195 When analysed by period, the displacements were significant only in some cases, but the global displacement was significant. Hence, in the first period (18 January 2016 - 18 February 2016), the displacement was only significant at point 3, in the second period (16 February 2016 - 10 March 2016) at points 4 and 6, and in the third period (10 March 2016 - 23 March 2016) at points 2 and 5. In the fourth period (23 March 2016-21 May 2016), which was the longest, displacements reached the highest values (up to $0.010 \mathrm{~m}$ ) and were significant at points 4, 5, 6, 7, and 8. Lastly, in the fifth period (21 May 2016 - 11 June 2016 ), the displacements were significant at points 6,7 , and 8 .

Table 4. Summary of effective N, E, and Z-axis displacements of GNSS points in Victoria, displaying the direction and speed of each horizontal and vertical point.

\begin{tabular}{llllllll}
\hline $\begin{array}{l}\text { GNSS } \\
\text { point }\end{array}$ & $\mathrm{N}(\mathrm{m})$ & $\mathrm{E}(\mathrm{m})$ & $\mathrm{Z}(\mathrm{m})$ & $\mathrm{D}_{\mathrm{NE}}(\mathrm{m})$ & $\begin{array}{l}\mathrm{V}_{\mathrm{H}}\left(\mathrm{m} \mathrm{month}^{-}\right. \\
1)\end{array}$ & $\begin{array}{l}\mathrm{V}_{\mathrm{V}} \\
\left.\text { month }^{-1}\right)\end{array}$ & (mirection \\
\hline 1 & -0.029 & 0.048 & -0.025 & 0.056 & 0.017 & -0.008 & $\mathrm{E}$ \\
2 & -0.028 & 0.104 & -0.031 & 0.108 & 0.035 & -0.010 & $\mathrm{E}$ \\
3 & -0.057 & 0.080 & -0.040 & 0.098 & 0.031 & -0.013 & $\mathrm{~S} 54.5^{\circ} \mathrm{E}$ \\
4 & 0.118 & 0.114 & -0.037 & 0.164 & 0.052 & -0.012 & $\mathrm{~N} 44.0^{\circ} \mathrm{E}$ \\
5 & 0.212 & -0.043 & -0.098 & 0.216 & 0.069 & -0.031 & $\mathrm{~N} 11.5^{\circ} \mathrm{W}$ \\
6 & 0.178 & -0.088 & -0.076 & 0.199 & 0.064 & -0.024 & $\mathrm{~N} 26.3^{\circ} \mathrm{W}$ \\
7 & 0.154 & -0.036 & -0.068 & 0.158 & 0.050 & -0.022 & $\mathrm{~N}$ \\
8 & 0.181 & -0.015 & -0.055 & 0.181 & 0.058 & -0.018 & $\mathrm{~N}$ \\
\hline
\end{tabular}

In the vertical displacements $\left(\mathrm{D}_{\mathrm{V}}\right)$, downward movements (negative values) were observed at all points, ranging from 0.037 to $0.098 \mathrm{~m}$, and were in general above the instrument accuracy of $0.035 \mathrm{~m}$, except at points 1 and 2 . The highest downward movements were observed in the head and main body (points 5, 6, and 7).

The velocities or displacement rates ranged from 0.013 to $0.069 \mathrm{~m} \mathrm{month}^{-1}$ in the horizontal component, although they were slightly higher at the top and main body (points 4, 5, 6, and 7), with rates ranging from 0.050 to $0.069 \mathrm{~m} \mathrm{month}^{-1}$, than in the foot (point 1) and flanks (2 and 3), which show minimum rates $\left(0.017-0.035 \mathrm{~m} \mathrm{month}^{-1}\right)$.

The vertical displacement rates also peaked in the head and main body zones (downward movements ranging from 0.022 to $0.031 \mathrm{~m} \mathrm{month}^{-1}$ ) and were lower at the landslide boundary (downward movements ranging from 0.008 to $0.013 \mathrm{~m} \mathrm{month}^{-1}$ ).

Table 5 presents the results of displacements, direction, and horizontal and vertical velocities at Colinas Lojanas with data from the GNSS network. Considering the horizontal accuracy threshold of $0.03 \mathrm{~m}+1$ ppm, points 3 and 21 were discarded because their values were below this threshold and did not represent significant displacement. The other points showed significant displacement values, ranging from 0.033 to $0.151 \mathrm{~m}$, and were generally lower than $0.053 \mathrm{~m}$ in the foot of the landslide (points 1, 2, 4, 5, 6, and 7), where the predominant direction is N. Conversely, the displacements were generally higher in the main body and head, showing values higher than $0.053 \mathrm{~m}$ at points $11,12,13,14,15,16,18,22,23$, and 24, and even higher than $0.109 \mathrm{~m}$ at points $8,9,10,17,19$, and 20 . The directions of displacement, with some variations, tended to be 
https://doi.org/10.5194/nhess-2021-32

Preprint. Discussion started: 8 February 2021

(c) Author(s) 2021. CC BY 4.0 License.

220 north-east (NE) in this zone of the body, although some points, such as 16 and 20, had south-eastward (SE) and north-westward (NW) directions, respectively.

Table 5. Summary of effective N, E, and Z-axis displacements of GNSS points in Colinas Lojanas, showing the direction and velocity of each horizontal and vertical point.

\begin{tabular}{llllllll}
\hline $\begin{array}{l}\text { GNSS } \\
\text { point }\end{array}$ & $\begin{array}{l}\mathrm{N} \\
(\mathrm{m})\end{array}$ & $\begin{array}{l}\mathrm{E} \\
(\mathrm{m})\end{array}$ & $\begin{array}{l}\mathrm{Z} \\
(\mathrm{m})\end{array}$ & $\begin{array}{l}\mathrm{D}_{\mathrm{NE}} \\
(\mathrm{m})\end{array}$ & $\begin{array}{l}\mathrm{V}_{\mathrm{H}} \\
\left(\mathrm{m} \mathrm{month}^{-1}\right)\end{array}$ & $\begin{array}{l}\mathrm{V}_{\mathrm{V}} \\
\left(\mathrm{m} \mathrm{month}^{-1}\right)\end{array}$ & Direction \\
\hline 1 & -0.015 & 0.029 & 0.038 & 0.033 & 0.010 & 0.011 & - \\
2 & 0.034 & 0.017 & 0.069 & 0.038 & 0.011 & 0.020 & $\mathrm{~N}$ \\
3 & 0.017 & 0.012 & 0.093 & 0.021 & 0.006 & 0.027 & - \\
4 & 0.036 & 0.016 & 0.104 & 0.039 & 0.011 & 0.030 & $\mathrm{NNE}$ \\
5 & 0.002 & 0.026 & 0.061 & 0.026 & 0.007 & 0.018 & $\mathrm{E}$ \\
6 & 0.035 & 0.018 & 0.036 & 0.039 & 0.011 & 0.010 & $\mathrm{NNE}$ \\
7 & 0.052 & 0.010 & -0.042 & 0.053 & 0.015 & -0.012 & $\mathrm{~N}$ \\
8 & 0.084 & 0.070 & -0.060 & 0.109 & 0.031 & -0.017 & $\mathrm{NE}$ \\
9 & 0.089 & 0.072 & 0.047 & 0.114 & 0.033 & 0.014 & $\mathrm{~N} 38.9 \mathrm{E}$ \\
10 & 0.097 & 0.078 & -0.126 & 0.124 & 0.036 & -0.036 & $\mathrm{~N} 38.8 \mathrm{E}$ \\
11 & 0.039 & 0.048 & -0.070 & 0.062 & 0.018 & -0.020 & $\mathrm{~N} 50.9 \mathrm{E}$ \\
12 & 0.026 & 0.049 & -0.057 & 0.055 & 0.016 & -0.016 & $\mathrm{ENE}$ \\
13 & 0.036 & 0.078 & -0.170 & 0.086 & 0.025 & -0.049 & $\mathrm{~N} 65.2 \mathrm{E}$ \\
14 & 0.018 & 0.065 & -0.051 & 0.067 & 0.019 & -0.015 & $\mathrm{ENE}$ \\
15 & -0.027 & 0.044 & -0.053 & 0.052 & 0.015 & -0.015 & $\mathrm{SE}$ \\
16 & -0.036 & 0.036 & -0.095 & 0.051 & 0.015 & -0.027 & $\mathrm{~S} 45.0 \mathrm{E}$ \\
17 & 0.143 & 0.050 & -0.108 & 0.151 & 0.044 & -0.031 & NNE 19.3 E \\
18 & 0.040 & 0.024 & -0.062 & 0.047 & 0.014 & -0.018 & NNE \\
19 & -0.028 & 0.114 & -0.184 & 0.117 & 0.034 & -0.053 & ESE \\
20 & 0.142 & -0.040 & -0.111 & 0.148 & 0.043 & -0.032 & N 15.7 W \\
21 & 0.024 & 0.023 & -0.111 & 0.033 & 0.010 & -0.032 & - \\
22 & 0.021 & 0.043 & -0.100 & 0.048 & 0.014 & -0.029 & ESE \\
23 & 0.036 & 0.031 & -0.051 & 0.048 & 0.014 & -0.015 & NE \\
24 & 0.048 & 0.034 & -0.042 & 0.059 & 0.017 & -0.012 & NNE \\
\hline & & & & & & &
\end{tabular}

The vertical displacements, at most points, exceeded the vertical accuracy threshold $(0.035 \mathrm{~m})$, although at some of them, specifically points $1,6,7$, and 24 , the vertical displacements only did so by $0.007 \mathrm{~m}$; therefore, these values can be considered nonsignificant. Most of the points distributed throughout the study area showed downward movements (negative displacements) of approximately $0.042 \mathrm{~m}$ and $0.184 \mathrm{~m}$ in the main body and head, respectively. Only a few points, in the foot 
https://doi.org/10.5194/nhess-2021-32

Preprint. Discussion started: 8 February 2021

(c) Author(s) 2021. CC BY 4.0 License.

230 (points 1, 2, 3, 4, 5, 6, and 9), specifically on the road to the north of the study area, showed upward movements lower than $0.10 \mathrm{~m}$.

The horizontal displacement rates ranged from 0.010 to $0.015 \mathrm{~m} \mathrm{month}^{-1}$ at points located on the foot, while these rates ranged from 0.018 to $0.043 \mathrm{~m} \mathrm{month}^{-1}$ in the main body and head. In turn, the vertical displacement rates of the landslide main body and head showed negative values (downward movements), ranging from 0.017 to $0.053 \mathrm{~m} \mathrm{month}^{-1}$, while positive values (upward movements) ranging from 0.020 to $0.030 \mathrm{~m} \mathrm{month}^{-1}$ were observed in the foot.

\subsection{Displacements in monitoring points assessed by RPAS}

The displacements at the monitoring points are shown in the corresponding vector maps for the Victoria (Fig. 7) and Colinas Lojanas sectors (Fig. 8) and are summarised in Tables 6-9. The results of the displacements measured at monitoring points extracted from the DSMs and orthophotos in the stable zones, to validate the accuracy of these data, are outlined in Table 6

240 (Victoria) and Table 7 (Colinas Lojanas), showing that the mean in each study area was lower than $0.047 \mathrm{~m}$ for the horizontal component (XY) and lower than $0.025 \mathrm{~m}$ in absolute value for the vertical component (Z). In turn, the squared mean errors were lower than $0.09 \mathrm{~m}$ for $\mathrm{XY}$ and lower than $0.07 \mathrm{~m}$ for $\mathrm{Z}$.
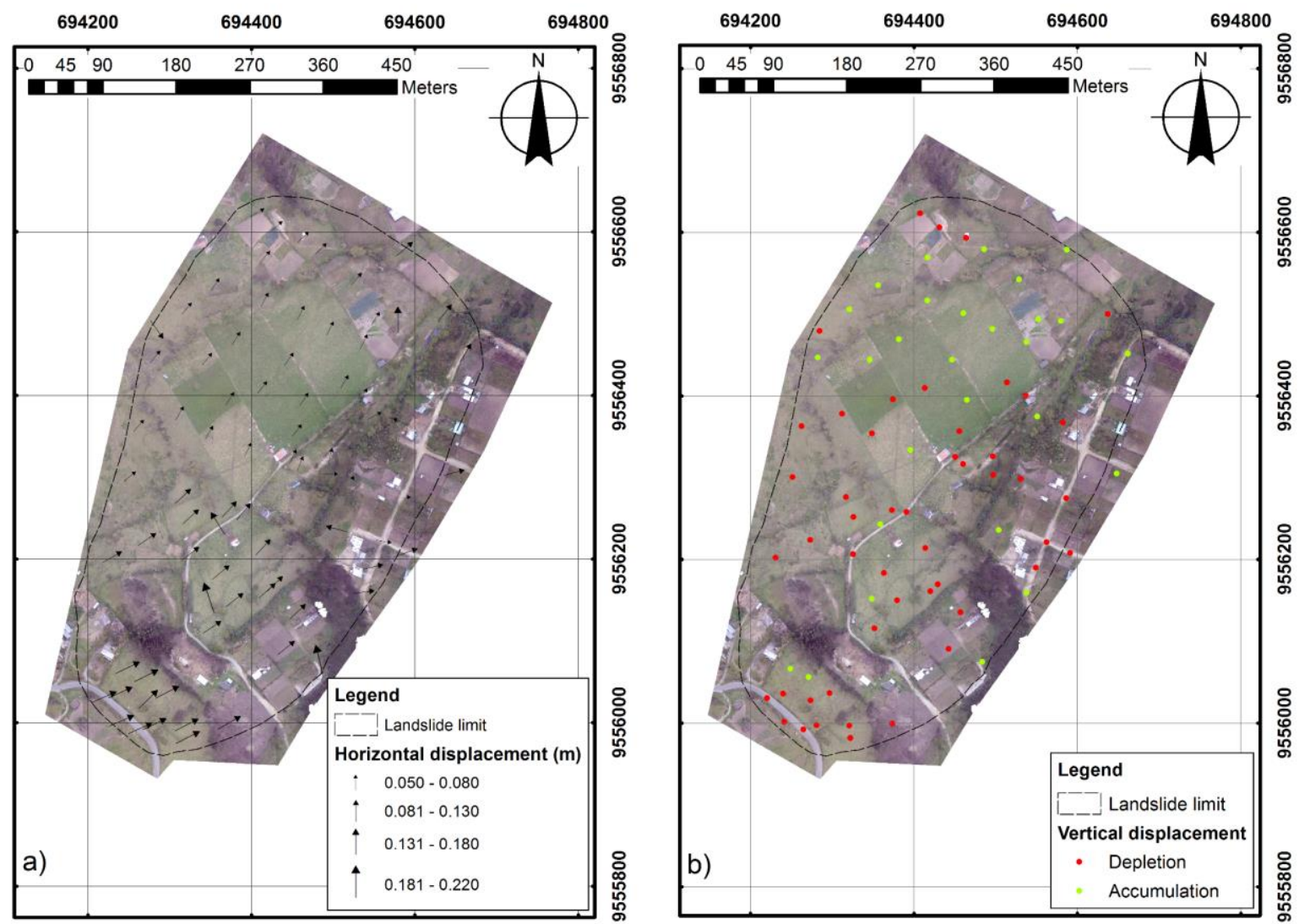
https://doi.org/10.5194/nhess-2021-32

Preprint. Discussion started: 8 February 2021

(c) Author(s) 2021. CC BY 4.0 License.

Figure 7. Map of horizontal a) and vertical b) displacement vectors of depletion and accumulation in the Victoria sector. Images
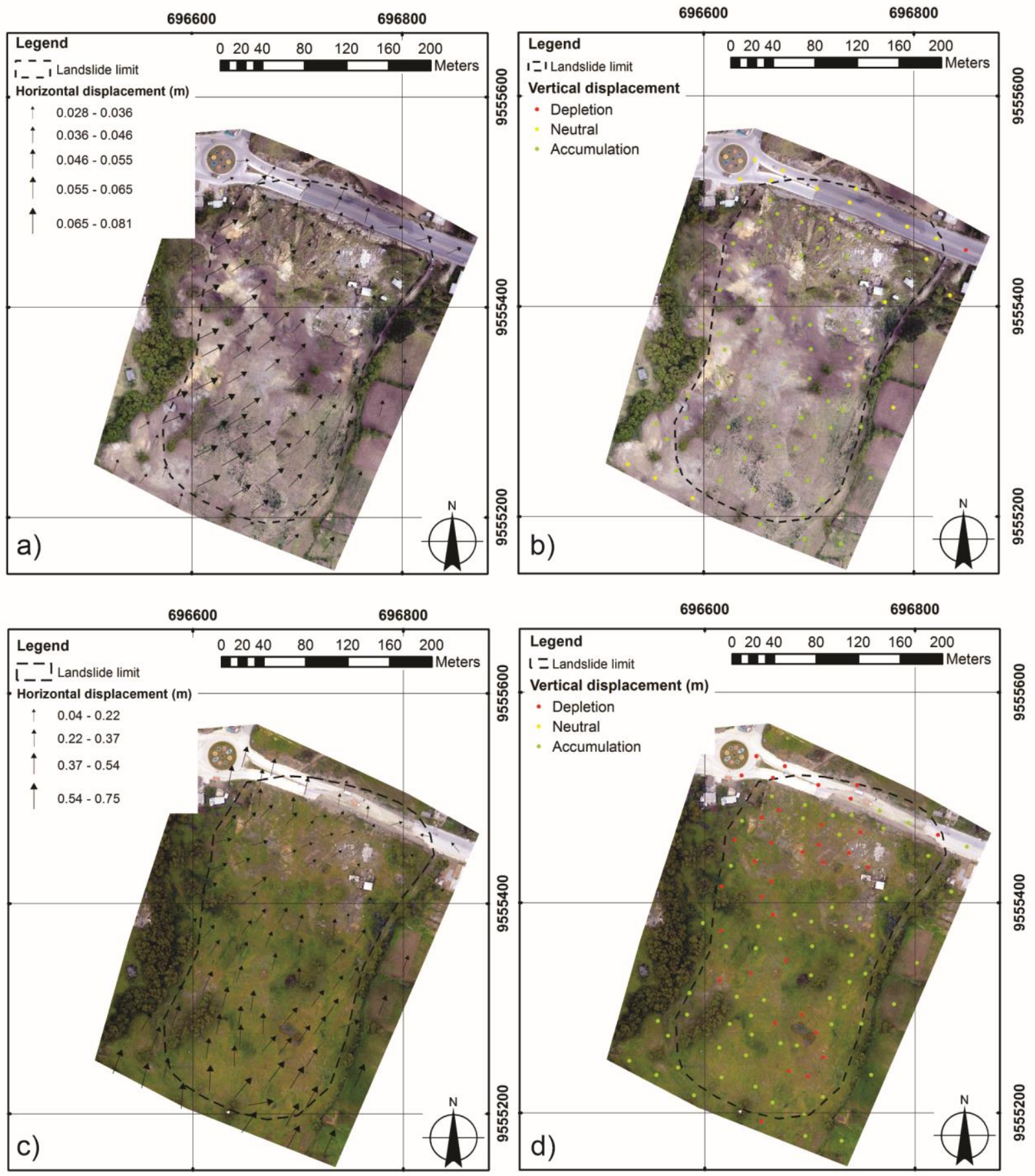
Figure 8. Map of direction and velocity vectors of the landslide area of the Colinas Lojanas sector. a) and b) correspond to the period from 4 July 2016 to 29 November 2016; c) and d) correspond to the period from 29 November 2016 to 12 January 2018.

Table 6. Summary of errors between flights in the Victoria sector. Displacements calculated between checkpoints in stable zones. M: mean; SD standard deviation; RMSE: root mean square error.

\begin{tabular}{|c|c|c|c|}
\hline \multirow{2}{*}{ Error XY } & \multicolumn{3}{|c|}{ Reference flight } \\
\hline & \multicolumn{3}{|c|}{18 February 2016} \\
\hline Comparison flight & $\mathrm{M}$ & SD & RMSE \\
\hline 11 June 2016 & 0.016 & 0.098 & 0.089 \\
\hline \multirow{2}{*}{ Error Z } & \multicolumn{3}{|c|}{ Reference flight } \\
\hline & \multicolumn{3}{|c|}{18 February 2016} \\
\hline Comparison flight & M & SD & RMSE \\
\hline 11 June 2016 & 0.010 & 0.074 & 0.068 \\
\hline
\end{tabular}

255 Table 7. Summary of errors between flights in the Colinas Lojanas sector. Displacements calculated between checkpoints in stable zones. M: mean; SD standard deviation; RMSE: root mean square error.

\begin{tabular}{|c|c|c|c|c|c|c|c|}
\hline \multirow{4}{*}{ 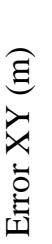 } & Reference flight & \multicolumn{3}{|c|}{4 July 2016} & \multicolumn{3}{|c|}{29 November 2016} \\
\hline & Comparison flight & $\mathrm{M}$ & SD & RMSE & $\mathrm{M}$ & SD & RMSE \\
\hline & $\begin{array}{ll}29 & \text { November } \\
2016 & \end{array}$ & 0.032 & 0.015 & 0.035 & - & - & - \\
\hline & 12 January 2018 & 0.029 & 0.018 & 0.032 & 0.047 & 0.073 & 0.081 \\
\hline ఏ્छ & $\begin{array}{ll}29 & \text { November } \\
2016 & \end{array}$ & -0.025 & 0.059 & 0.061 & - & - & - \\
\hline $\begin{array}{c}N \\
\dot{0} \\
\stackrel{0}{ \pm}\end{array}$ & 12 January 2018 & -0.027 & 0.049 & 0.058 & -0.019 & 0.066 & 0.065 \\
\hline
\end{tabular}


Table 8. Horizontal and vertical displacements and velocities calculated at monitoring points extracted in the landslide area of the Victoria sector. Displacements are expressed as $\mathbf{m}$ and velocities as $\mathbf{m} \mathbf{m o n t h}^{\mathbf{1}}$.

\begin{tabular}{|c|c|c|c|c|c|c|c|c|c|c|}
\hline & & \multirow[b]{2}{*}{ Period } & \multicolumn{2}{|c|}{ Total } & \multicolumn{2}{|c|}{ Head } & \multicolumn{2}{|c|}{ Main body } & \multicolumn{2}{|c|}{ Foot } \\
\hline & & & $\begin{array}{l}\text { Absolute } \\
\text { (m) }\end{array}$ & $\begin{array}{c}\text { Velocity } \\
(\mathrm{m} \\
\left.\text { month }^{-1}\right)\end{array}$ & $\begin{array}{c}\text { Absolute } \\
\text { (m) }\end{array}$ & $\begin{array}{c}\text { Velocity } \\
\text { (m month- } \\
1 \text { ) }\end{array}$ & $\begin{array}{l}\text { Absolute } \\
\text { (m) }\end{array}$ & $\begin{array}{c}\text { Velocity (m } \\
\text { month }^{-1} \text { ) }\end{array}$ & Absolute (m) & $\begin{array}{c}\text { Velocity (m } \\
\text { month }^{-1} \text { ) }\end{array}$ \\
\hline 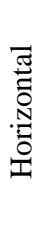 & 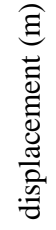 & $\begin{array}{l}18 \text { February } \\
2016-11 \text { June } \\
2016\end{array}$ & 0.103 & 0.026 & 0.145 & 0.038 & 0.081 & 0.021 & 0.081 & 0.021 \\
\hline 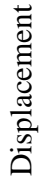 & $\begin{array}{l}\widehat{\Xi} \\
\stackrel{\Xi}{\Xi} \\
\stackrel{\Xi}{0}\end{array}$ & $\begin{array}{l}18 \text { February } \\
2016-11 \text { June } \\
2016\end{array}$ & -0.079 & -0.021 & -0.092 & -0.024 & -0.085 & -0.022 & 0.211 & 0.055 \\
\hline
\end{tabular}

Table 9. Horizontal and vertical displacements and velocities calculated at monitoring points in the landslide area of the Colinas Lojanas sector. Displacements are expressed as $\mathbf{m}$ and velocities as $\mathbf{m} \mathbf{m o n t h}^{-1}$.

\begin{tabular}{|c|c|c|c|c|c|c|c|c|c|}
\hline \multirow{6}{*}{ 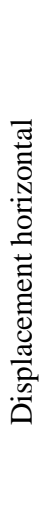 } & \multirow[b]{2}{*}{ Period } & \multicolumn{2}{|l|}{ Total } & \multicolumn{2}{|l|}{ Head } & \multicolumn{2}{|c|}{ Main body } & \multicolumn{2}{|l|}{ Foot } \\
\hline & & $\begin{array}{l}\text { Absolute } \\
\text { (m) }\end{array}$ & $\begin{array}{l}\text { Velocity }(\mathrm{m} \\
\left.\text { month }^{-1}\right)\end{array}$ & $\begin{array}{l}\text { Absolute } \\
\text { (m) }\end{array}$ & $\begin{array}{l}\text { Velocity } \\
\text { (m month- } \\
\text { 1) }\end{array}$ & $\begin{array}{l}\text { Absolute } \\
\text { (m) }\end{array}$ & $\begin{array}{l}\text { Velocity } \\
\text { (m month- } \\
{ }^{1} \text { ) }\end{array}$ & $\begin{array}{l}\text { Absolute } \\
\text { (m) }\end{array}$ & $\begin{array}{l}\text { Velocity } \\
\text { (m month- } \\
{ }^{1} \text { ) }\end{array}$ \\
\hline & $\begin{array}{l}4 \text { July } 2016- \\
29 \text { November } \\
2016\end{array}$ & 0.052 & 0.010 & 0.056 & 0.011 & 0.054 & 0.011 & 0.045 & 0.001 \\
\hline & 29 November & & & & & & & & \\
\hline & 2016-12 & 0.356 & 0.025 & 0.531 & 0.038 & 0.316 & 0.022 & 0.221 & 0.016 \\
\hline & January 2018 & & & & & & & & \\
\hline 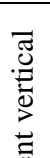 & $\begin{array}{l}4 \text { July 2016- } \\
29 \text { November } \\
2016\end{array}$ & 0.184 & 0.037 & -0.165 & -0.033 & -0.325 & -0.065 & 0.063 & 0.013 \\
\hline $\begin{array}{l}\frac{\mathscr{\Xi}}{0} \\
\frac{\pi}{0} \\
\frac{\pi}{2} \\
\frac{n}{0}\end{array}$ & $\begin{array}{l}29 \text { November } \\
2016- \\
\text { January }\end{array}$ & 0.194 & 0.014 & -0.342 & -0.024 & -0.187 & -0.013 & 0.054 & 0.004 \\
\hline
\end{tabular}


The displacements calculated in the unstable zones are shown in Tables 8 and 9, further differentiating the upper (head), middle (main body), and lower (foot) sections of the landslide.

The map of horizontal displacement vectors of the Victoria sector in the study period (18 February 2016 - 11 June 2016) (Fig. 7a) shows that the points with the highest displacement were found in the SW, which corresponded to the upper area of the landslide, or head, and decreased down the landslide toward the main body and foot. The trend was almost always towards the NE (range between N049 and N059), although occasionally some points deviated to the N and even to the NW. Thus, in the summary of values presented in Table 8 , the horizontal displacements averaged $0.145 \mathrm{~m}$ in the head, while the mean values in the main body and foot were both cases $0.081 \mathrm{~m}$. In terms of displacement rate or velocity, the mean value in the head was $0.038 \mathrm{~m} \mathrm{month}^{-1}$, decreasing to $0.021 \mathrm{~m} \mathrm{month}^{-1}$ in the main body and foot. Fig. $7 \mathrm{~b}$ shows that the vertical displacements were predominantly negative, expressing downward movement or depletion, especially in the head of the landslide and, to some extent, in the body and foot, where many points were positive, expressing upward movement or accumulation. Thus, in the summary of Table 8 , the average vertical displacement was $-0.092 \mathrm{~m}$ in the main body $-0.085 \mathrm{~m}$ and $0.211 \mathrm{~m}$ in the foot. The velocities in the different parts were $-0.024,-0.022$ and $0.055 \mathrm{~m} \mathrm{month}^{-1}$, respectively.

Figure 8 shows the horizontal and vertical displacement vectors corresponding to the periods from July to November 2016 (Fig. 8a and b) and November 2016 to January 2018 (Fig. 8c and d) in the Colinas Lojanas sector. In the first period, the highest displacement values were concentrated in the $\mathrm{S}$ (head) and W (left flank) zones, decreasing towards the $\mathrm{N}$ and $\mathrm{E}$ (Fig. 8a) along the landslide towards the foot. The general displacement direction was NNE (N029-N038), although the

displacement turned more towards the $\mathrm{N}$ in the foot. The values outlined in Table 9 show a rather uniform mean horizontal displacement in the head and the main body of the landslide ( 0.056 and $0.054 \mathrm{~m}$, respectively), slightly decreasing towards the foot $(0.045 \mathrm{~m})$. The velocity averaged $0.011 \mathrm{~m} \mathrm{month}^{-1}$ in the head and main body and $0.001 \mathrm{~m} \mathrm{month}^{-1}$ in the foot.

In the second period, the map of horizontal displacement vectors (Fig. 8c) also showed a decrease in displacement modulus from SW (head) to NE (foot), with a tendency towards NNE (N029-N039), albeit with a greater dispersion of directions in some points between ENE and NW. In summary in Table 9, the mean horizontal displacements range from $0.531 \mathrm{~m}$ in the head to $0.316 \mathrm{~m}$ in the main body, and $0.221 \mathrm{~m}$ in the foot, which in velocity terms meant $0.038 \mathrm{~m} \mathrm{month}^{-1}, 0.022 \mathrm{~m} \mathrm{month}^{-1}$, and $0.016 \mathrm{~m} \mathrm{month}^{-1}$, respectively.

The vertical displacements varied in a different way between the two periods. Accordingly, the values of Table 9 show that, in the first period (4 July 2016 - 29 November 2016), the mean displacements were higher in the head (0.165 m) and main body $(0.325 \mathrm{~m})$ than in the foot, where they decreased to values of $0.063 \mathrm{~m}$ of upward movement or accumulation. The velocity was higher in the head and main body (0.033 and $0.065 \mathrm{~m} \mathrm{month}^{-1}$, respectively) and lower in the foot $\left(0.013 \mathrm{~m} \mathrm{month}{ }^{-1}\right)$. In the second period (29 November 2016 - 12 January 2018), the mean vertical displacement values were $-0.342 \mathrm{~m}$ in the head, $-0.187 \mathrm{~m}$ in the body, and $0.054 \mathrm{~m}$ in the foot, which in terms of velocity meant $0.024 \mathrm{~m} \mathrm{month}^{-1}, 0.013 \mathrm{~m} \mathrm{month}^{-1}$, and -0.004 
https://doi.org/10.5194/nhess-2021-32

Preprint. Discussion started: 8 February 2021

(c) Author(s) 2021. CC BY 4.0 License.

$\mathrm{m}$ month $^{-1}$, that is, gradually decreasing from the head to the main body and foot of the landslide. The head and main body showed downward movements, and the foot showed upward movements. Vegetation changes mainly influence the determination of terrain elevation changes due to the use of digital surface models.

\subsection{Digital surface models and resulting accuracies}

\subsubsection{Differential models}

The DoDs are shown in Fig. 9a (Victoria) and, b and c (Colinas Lojanas). The colour palette has been designed and adjusted to identify subtle changes in the DoD, which made it possible to stretch the colour palette at lower values. In addition, the trimodal colour palette set negative (in blue) and positive values (in red), the former corresponding to a downward movement and the latter to an upward movement of the terrain.
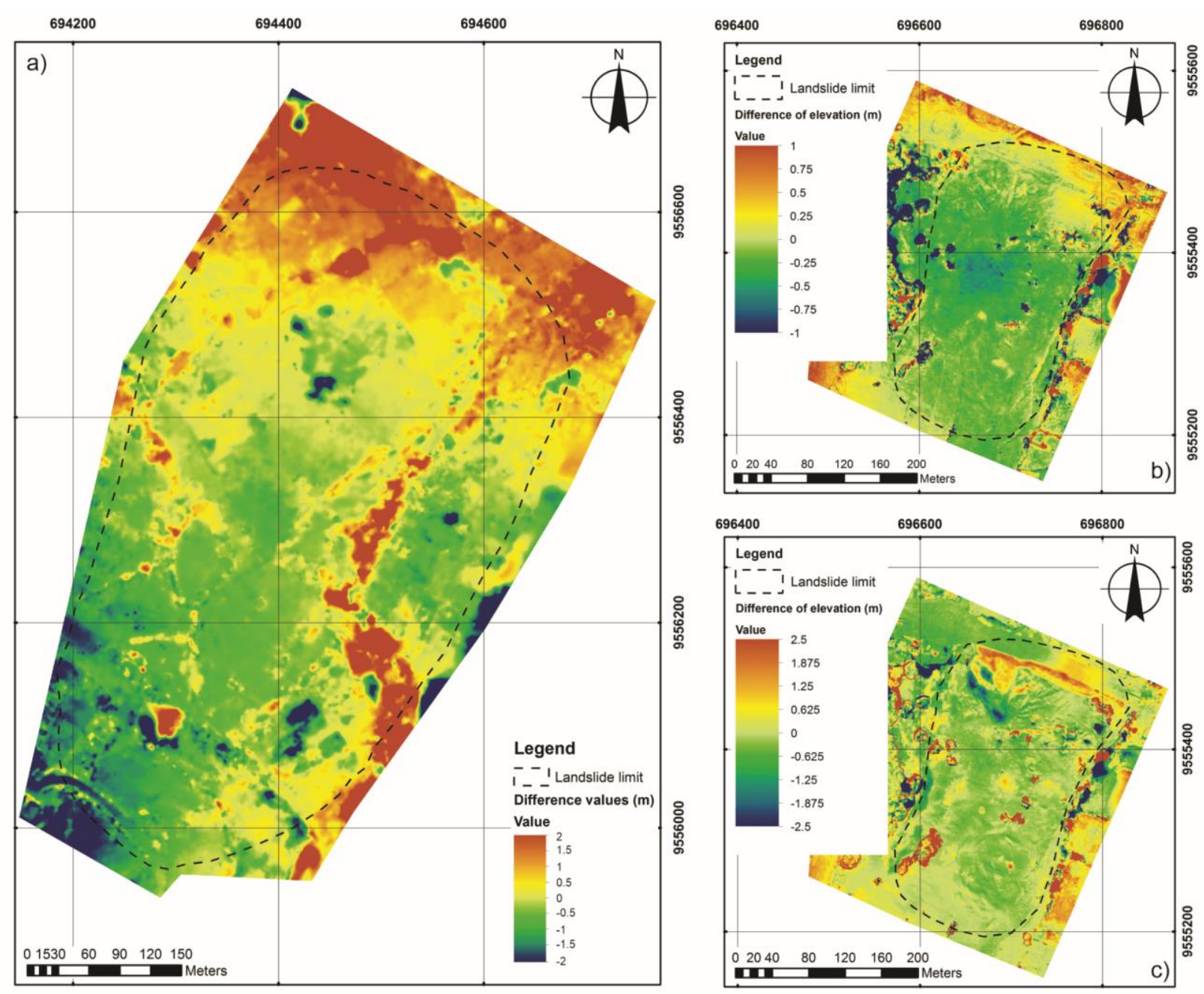
https://doi.org/10.5194/nhess-2021-32

Preprint. Discussion started: 8 February 2021

(C) Author(s) 2021. CC BY 4.0 License.

Fig. 9 DoD maps a) corresponding to Victoria (18 February 2016 - 11 June 2016), b) Colinas Lojanas (July - November 2016 period) and c) Colinas Lojanas (November 2016 - January 2018 period). Images generated and processed in ArcGIS.

Thus, the Victoria sector showed downward movements of the surface predominantly in the upper part of the landslide (head) and upward movements predominantly in the lower part (foot), with a gradient from the highest negative values in absolute terms to the highest values in absolute terms when moving down the slope, reaching the lowest values in absolute terms in the central zone. In addition, some areas had marked downward and upward movements that contrasted with the surrounding areas more moderate changes in slope, as well as a general upward zone near the left flank overlapping with a densely vegetated thalweg or ravine, as shown in the orthophotos (Fig. 5a and b).

In the Colinas Lojanas sector, the DoDs were interpolated for the two study periods: July - November 2016 (Fig. 9b) and November 2016 - January 2018 (Fig. 9c). In the first period, the downward (negative) zone was identified at the head and main body, along with a slight accumulation in the foot. In the second period, displacement was highlighted by the accumulation of material at the foot and by depletion (loss of material) in some cracks, as shown in Fig. 6a, c and e. This downward movement of the surface at the head and main body increased down the slope to the foot, next to the road, which showed significant upward movements.

\section{Discussion}

\subsection{Accuracies and errors}

325 In the analysis of displacements from GNSS points, uncertainty was estimated from the combined error in the measurement of the points (1) (2), which, according to the error propagation rule (Bossi et al., 2015; Fernández et al., 2016; Wheaton et al., 2010), is:

$$
\begin{aligned}
& R M S_{X Y}=\left(R M S_{X Y 1}^{2}+R M S_{X Y 2}^{2}\right)^{1 / 2} \\
& R M S_{Z}=\left(R M S_{Z 1}^{2}+R M S_{Z 2}^{2}\right)^{1 / 2}
\end{aligned}
$$

330 Thus, based on values of $0.030 \mathrm{~m}$ for horizontal error and $0.035 \mathrm{~m}$ for vertical error of the GNSS, uncertainty was estimated at $0.04 \mathrm{~m}$ and $0.05 \mathrm{~m}$, respectively.

In turn, in the analysis of displacements based on UAV flights and their images, uncertainty was estimated in two ways. First, uncertainty was estimated based on errors of the orientation process calculated at control and checkpoints, provided by the PhotoScan software (Table 3). These errors, which were assumed to be uncertainty, were smaller than $0.10 \mathrm{~m}$ for virtually all

335 flights in both study areas, for both horizontal (XY) and vertical (Z) components, which generally corroborated those assessed in previous studies (Carvajal et al., 2012; Eltner et al., 2016; Kršák et al., 2016; Vrublová et al., 2015) and they were within the ranges established by the American Society for Photogrammetry and Remote Sensing. 
Second, the mean values, standard deviation (SD), and root mean square error (RMSE) were calculated from displacements between points located in stable areas, which theoretically should be null at those points. The mean tells us about the general agreement between models and images (DSMs and orthophotos) from different periods, while the SD and RMSE tell us about the individual agreement between them. Thus, the SD and RMSE values measure the uncertainty in the horizontal and vertical components of the displacements between points (Fernández et al., 2016). These values generally ranged from 0.05 and 0.10 $\mathrm{m}$ for both components, so they were on the same order as the aforementioned control and checkpoint errors and those assessed in previous studies based on RPAS surveys (Fernández et al., 2015, 2016) when setting an uncertainty threshold of $0.10 \mathrm{~m}$ for horizontal and vertical displacements, above which displacements are considered significant.

\subsection{Analysis of displacements in unstable zones}

The horizontal and vertical displacement vectors assessed by processing RPAS flights make it possible to approximately delimit stable and unstable areas and, within these areas, identify different sectors with more or less intense movements.

In the Victoria study area, the horizontal displacement vectors maintained a consistent movement, with a tendency towards $\mathrm{N}$ and NE, although deviations from this trend were observed on the flanks, towards the centre of the zone of depletion, or in other directions, due to the unevenness of the ground surface. The values of horizontal displacements were higher in the upper zone or head, where they generally exceeded the uncertainty threshold $(0.10 \mathrm{~m})$, reaching means close to $0.15 \mathrm{~m}$ and even higher values at some points. These values decreased towards the middle (main body) and lower (foot) parts of the landslide, where means were lower than the uncertainty threshold $(0.08 \mathrm{~m})$. However, in some points, the threshold was exceeded and therefore ground movement occurred in these sectors. Based on the above, the maximum deformation occurred in the head where cracks and other landslides elements formed. The estimated velocities, which ranged from $0.046 \mathrm{~m} \mathrm{month}^{-1}$ in the head to $0.026 \mathrm{~m} \mathrm{month}^{-1}$ in the main body and foot, are typical of a very slow movement (Cruden and Varnes, 1996; Hungr et al., 2014; WP/WLI, 1993). The horizontal displacements measured with greater accuracy in GNSS points were consistent with the above. Thus, the displacements at points of the head reached values close to $0.20 \mathrm{~m}$, while they decreased to values close to $0.06 \mathrm{~m}$ in the foot and flanks, which in velocity terms mean $0.070 \mathrm{~m} \mathrm{month}^{-1}$ and $0.016 \mathrm{~m} \mathrm{month}^{-1}$, respectively, and in the latter they are virtually at the limit of extremely slow movements. By period, although the displacements were most often nonsignificant in absolute terms, the mean velocity of the set of points showed considerable variations, ranging from $0.020 \mathrm{~m}$ month $^{-1}$ (near the limit between extremely slow and very slow) and $0.070 \mathrm{~m} \mathrm{month}^{-1}$ (very slow).

The vertical displacements were generally lower than horizontal displacements, which usually indicates flow-type movements (Cruden and Varnes, 1996; Fernández et al., 2016; Hungr et al., 2014). The vertical displacements were predominantly negative, which indicates that the terrain tended to move downward through slope kinematics, and they were clearly above the significance threshold at the head $(0.092 \mathrm{~m})$ and near this threshold at the main body $(0.085 \mathrm{~m})$. At the foot, however, they were significant and positive $(0.211 \mathrm{~m})$, which is typical of zones of accumulation. For horizontal displacements, the highest value of vertical displacement indicates maximum deformation at the head, forming scarps, stepped terraces, and cracks. The 
https://doi.org/10.5194/nhess-2021-32

rates of vertical velocity ranged from $-0.112 \mathrm{~m} \mathrm{month}^{-1}$ to $-0.027 \mathrm{~m} \mathrm{month}^{-1}$ at the head and main body (a very slow downward movement) and $0.067 \mathrm{~m} \mathrm{month}^{-1}$ (very slow upward movement). The GNSS data generally corroborated these kinematics, with lower, albeit significant, displacement and velocity values (also classified as very slow). The GNSS data by period also showed only significant vertical displacements between some points, although the same variations in velocities were generally observed between the different study periods, as observed in the horizontal displacements.

375 In conclusion, considering the horizontal and vertical displacements, the corresponding rates, and their distribution, a flow process was active during the study period in the Victoria sector, specifically downhill creep. This movement showed very slow to extremely slow displacement rates, with some phases of increased deformation transitioning towards flow. The deformation was higher at the head, with horizontal and vertical decimetre displacements, and lower at the foot, with nonsignificant horizontal displacements and slight upward vertical displacements, indicating accumulation of material in this zone.

The Colinas Lojanas sector in the first study period showed horizontal displacements with a fairly uniform tendency towards $\mathrm{N}-\mathrm{NE}$, which rotated slightly towards $\mathrm{N}$ at the foot. This tendency was upheld in the second period, albeit with a greater dispersion of directions between NW and E. The modulus of the vectors (approximately $0.05 \mathrm{~m}$ ) did not generally exceed the significance threshold, but the values were higher than $0.10 \mathrm{~m}$ at some points, indicating some activity in the area, as confirmed by the displacement values at GNSS points, which were $0.073 \mathrm{~m}$ at the head, $0.084 \mathrm{~m}$ at the main body, and $0.036 \mathrm{~m}$ at the foot. These values translate into velocities of $0.027 \mathrm{~m} \mathrm{month}^{-1}, 0.024 \mathrm{~m} \mathrm{month}^{-1}$, and $0.012 \mathrm{~m} \mathrm{month}^{-1}$, that is, a very slow movement, which actually fell below the threshold of extremely slow movement at the foot.

The vertical displacements of downward movement were above the significance threshold in the head and main body $(0.165$ $\mathrm{m}$ and $0.325 \mathrm{~m})$ and below the threshold at the foot $(0.063 \mathrm{~m})$. The displacements measured with GNSS generally confirm the

390 values assessed by RPAS and are significant in all cases, although positive displacements of upward ground movement were measured at the foot. Velocity ranged from $0.024 \mathrm{~m} \mathrm{month}^{-1}$ to $0.033 \mathrm{~m} \mathrm{month}^{-1}$ at the head (in absolute terms), that is, slow movements, albeit close to the threshold of extremely slow movements.

In the second study period, the horizontal displacements were clearly above the significance threshold, peaking at the head $(0.531 \mathrm{~m})$ and decreasing towards the main body $(0.316 \mathrm{~m})$ and foot $(0.221 \mathrm{~m})$. Velocity was $0.038 \mathrm{~m} \mathrm{month}^{-1}, 0.022 \mathrm{~m}^{2} \mathrm{month}^{-}$

$395{ }^{1}$ and $0.016 \mathrm{~m} \mathrm{month}^{-1}$, respectively, that is, very slow, albeit higher than those of the first period. Major displacements stood out at the head, indicating higher deformation in this zone than in the lower parts of the landslide. The vertical displacements were negative at the head and main body $(-0.342 \mathrm{~m}$ and $-0.187 \mathrm{~m})$, exceeding the significance threshold, and positive at the foot $(0.054 \mathrm{~m})$, albeit below the significance threshold. These findings indicate downward movement of the displaced mass with accumulation towards the foot, producing maximum deformation at the head. These rates also correspond to a very slow movement. 
The above suggests the existence of a downhill creep process, which is particularly evident in the first period, with very slow to extremely slow movements of displaced mass. The movement shows no considerable differences between the different zones of the unstable area, and the horizontal and vertical displacements are quite similar and low. In the second period, the displacements and velocities are higher in general. Differences are also identified between different zones, with higher deformation at the head area than at the foot - where material is accumulated - and with more horizontal than vertical development. This suggests some acceleration of the process in this second phase compared to the first, most likely shifting from a downhill creep process, with little deformation, to a flow process, with more deformation.

\subsection{Differential models}

The differential models interpolated by DSM subtraction were used to visually assess the characteristics and evolution of the study landslides and to estimate the vertical, and in part the horizontal, displacements (Cardenal et al., 2019; Fernández et al., 2016). In addition, increases in surface elevation corresponded to changes not only in terrain elevation but also in vegetation cover. In general, predominant downward movements of the ground surface were identified at the head and predominant upward movements at the foot, which are typical of landslides with scarp zones at the head and accumulation of material at the foot. In the scarps, downward and forward movements, with loss of material, translated into downward movement of the ground surface; in contrast, at the foot, the forward movement of the mass itself elevated the surface when comparing the models, which was eventually reinforced with true upward movements due to the accumulation of material (Cardenal et al., 2019; Fernández et al., 2016). In turn, the zones with sporadic and highly marked downward and upward movements, which contrasted with the surrounding zones, primarily resulted from changes in vegetation and crops, although some construction may eventually have occurred. Thus, some of these zones had well-defined geometric shapes, with both upward and moderately downward movements, which, when observing the orthophotos, were clearly interpreted as crops either grown or reaped in the study period.

Conversely, other sectors had more intense changes, generally consisting of upward movements, which corresponded to zones of tree or shrub growth. This was mainly observed near the right flank, through which a gully runs and where there was intense vegetation growth in that period, and in other zones at the head, foot, and main body, where vegetation also clearly grew. Nevertheless, when avoiding these effects, the subtle movement of the terrain is evidenced in the study area.

In the Colinas Lojanas sector in the first period (July - November 2016), few changes were observed in the models within the movement zone. The most abrupt changes occurred in woodlands and generally corresponded to tree growth (upward movements of the DSM) although downward-upward movements also occurred due to the limited accuracy of DSMs in these woodlands. Only moderate general upward movement was observed in the main body of the landslide, while slight downward movements were observed in the head and main body, albeit non-significant. In the second period (November 2016 - January 2018), some zones showed abrupt changes of irregular shapes, with both upward and downward movements, which occurred sporadically in tree or shrub areas and could be equally attributed to tree changes (growth, pruning, and cutting, for example) 
https://doi.org/10.5194/nhess-2021-32

Preprint. Discussion started: 8 February 2021

(C) Author(s) 2021. CC BY 4.0 License.

as to the accuracy of the DSM. However, a more or less generalised downward movement was also observed in the main body and head, despite some plant growth in this zone. Nevertheless, the most visible changes occurred in the main body and foot of the landslide, where downward movements may have corresponded to an area of scarp or secondary terrace, and significant upward movements at the foot, next to the road, resulted from both a horizontal forward movement of the ground mass and a true upward movement of the surface as the mass of material accumulated. The road itself is raised; therefore, the upward movement of the surface corroborates the displacement of the points.

\section{Conclusions}

440 The monitoring technique by GNSS demonstrates the accuracy of this technology, which can detect centimetre deformations in short periods and under all weather circumstances (rain, mist, fog, strong sunshine, by night). RPAS remains a useful tool for rapid surveys, with centimetre resolution and centimetre-decimetre accuracy, on plots smaller than $100 \mathrm{~km}^{2}$. The latter has the advantage of enabling a survey of the entire surface.

Both techniques estimate deformations by measuring horizontal or vertical displacements. In GNSS they are determined

445 directly from points measured on the ground. In contrast, in RPAS they are determined from points extracted from the DSMs and orthophotos resulting from UAV image processing by SfM and MVS. The advantage is that these points can be extracted later, after examining the DSMs and the orthophotos. Also, DoDs can be constructed to estimate vertical and even horizontal displacements of the terrain surface. Lastly, RPAS techniques provide a very general view of the phenomenon, though since they use DSM and not DTM on the one hand and combine horizontal and vertical movement parameters on the other hand, the data must be interpreted carefully. Accordingly, combining this technique with the calculation of displacements between monitoring points and with the accurate measurement of GNSS points makes it possible to determine the kinematics of movement with high resolution, even in cases of subtle movements, such as those discussed above.

Thus, the techniques described in the present study show that the two landslides had a predominantly NE direction. In Victoria, the horizontal velocity ranged from 0.017 to $0.069 \mathrm{~m} \mathrm{month}^{-1}$, and the vertical downward velocity ranged from -0.008 to $0.031 \mathrm{~m} \mathrm{month}^{-1}$, so this movement is classified as very slow. In Colinas Lojanas, the horizontal velocities ranged from 0.006 to $0.044 \mathrm{~m} \mathrm{month}^{-1}$. As for the vertical velocities, two ranges were defined for upward (0.010 to $\left.0.030 \mathrm{~m} \mathrm{month}^{-1}\right)$ and downward movements $\left(-0.012\right.$ to $\left.-0.053 \mathrm{~m} \mathrm{month}^{-1}\right)$. Thus, these movements are also classified as very slow.

Future research could focus on improving the methodology by studying the generation of DSMs using RPAS with the application of filters to eliminate vegetation to reduce its effect on displacement measurements. Filtering is expected to improve the accuracy of DTM-based measurements. 
https://doi.org/10.5194/nhess-2021-32

Preprint. Discussion started: 8 February 2021

(c) Author(s) 2021. CC BY 4.0 License.

(c) (i)

\section{Acknowledgements}

We thank Rober Yanangomez for field assistance and Private Technical University of Loja through the Department of Geology and Mines and Civil Engineering for its logistical and laboratory support for the realization of this study.

\section{References}

Agisoft: Agisoft PhotoScan User Manual: Professional Edition, Copyr. (C) 2018 Agisoft LLC, (Version 1.4), 127, doi:10.1016/j.bjps.2011.05.024, 2018.

Agüera-Vega, F., Carvajal-Ramírez, F. and Martínez-Carricondo, P.: Accuracy of Digital Surface Models and Orthophotos

Derived from Unmanned Aerial Vehicle Photogrammetry, J. Surv., 143(2), 1-10, doi:10.1061/(ASCE)SU.19435428.0000206., 2016.

Agüera-Vega, F., Carvajal-Ramírez, F., Martínez-Carricondo, P., Sánchez-Hermosilla López, J., Mesas-Carrascosa, F., García-Ferrer, A. and Pérez-Porras, F.: Reconstruction of extreme topography from UAV structure from motion photogrammetry, Meas. J. Int. Meas. Confed., 121(February), 127-138, doi:10.1016/j.measurement.2018.02.062, 2018.

475 Akbarimehr, M., Motagh, M. and Haghshenas-Haghighi, M.: Slope stability assessment of the sarcheshmeh landslide, northeast Iran, investigated using InSAR and GPS observations, Remote Sens., 5(8), 3681-3700, doi:10.3390/rs5083681, 2013.

Al-Rawabdeh, A., Al-Gurrani, H., Al-Durgham, K., Detchev, I., He, F., El-Sheimy, N. and Habib, A.: A robust registration algorithm for point clouds from UAV images for change detection, Int. Arch. Photogramm. Remote Sens. Spat. Inf. Sci. ISPRS Arch., 2016-Janua(July), 765-772, doi:10.5194/isprsarchives-XLI-B1-765-2016, 2016.

ASPRS: Asprs Accuracy Standards for Large-Scale Maps, 1990.

Assilzadeh, H., Levy, J. K. and Wang, X.: Landslide catastrophes and disaster risk reduction: A GIS framework for landslide prevention and management, Remote Sens., 2(9), 2259-2273, doi:10.3390/rs2092259, 2010.

Bellone, T., Dabove, P., Manzino, A. M. and Taglioretti, C.: Real-time monitoring for fast deformations using GNSS low-cost receivers, Geomatics, Nat. Hazards Risk, 7(2), 458-470, doi:10.1080/19475705.2014.966867, 2014.

Boccardo, P., Chiabrando, F., Dutto, F., Tonolo, F. G. and Lingua, A.: UAV deployment exercise for mapping purposes: Evaluation of emergency response applications, Sensors (Switzerland), 15(7), 15717-15737, doi:10.3390/s150715717, 2015. 
https://doi.org/10.5194/nhess-2021-32

Preprint. Discussion started: 8 February 2021

(c) Author(s) 2021. CC BY 4.0 License.

Bossi, G., Cavalli, M., Crema, S., Frigerio, S., Quan Luna, B., Mantovani, M., Marcato, G., Schenato, L. and Pasuto, A.: Multitemporal LiDAR-DTMs as a tool for modelling a complex landslide: A case study in the Rotolon catchment (eastern Italian Alps), Nat. Hazards Earth Syst. Sci., 15(4), 715-722, doi:10.5194/nhess-15-715-2015, 2015.

Brückl, E., Brunner, F. K. and Kraus, K.: Kinematics of a deep-seated landslide derived from photogrammetric, GPS and geophysical data, Eng. Geol., 88(3-4), 149-159, doi:10.1016/j.enggeo.2006.09.004, 2006.

Capilla, R. M., Berné, J. L., Martín, A. and Rodrigo, R.: Simulation case study of deformations and landslides using real-time GNSS precise point positioning technique, Geomatics, Nat. Hazards Risk, 7(6), 1856-1873, doi:10.1080/19475705.2015.1137243, 2016.

Car, M., Kaćunić, D. J. and Kovačević, M.-S.: Application of Unmanned Aerial Vehicle for Landslide Mapping, Int. Symp. Eng. Geod., 549-560, 2016.

Carvajal, F., Agüera, F. and Pérez, M.: Surveying a Landslide in a Road Embankment Using Unmanned Aerial Vehicle Photogrammetry, ISPRS - Int. Arch. Photogramm. Remote Sens. Spat. Inf. Sci., XXXVIII-1/(September), 201-206, doi:10.5194/isprsarchives-XXXVIII-1-C22-201-2011, 2012.

Cavalli, M. and Marchi, L.: Characterisation of the surface morphology of an alpine alluvial fan using airborne LiDAR, Nat. Hazards Earth Syst. Sci., 8, 323-333, doi:10.5194/nhess-8-323-2008, 2008.

Chen, B., Yang, Y., Wen, H., Ruan, H., Zhou, Z., Luo, K. and Zhong, F.: High-resolution monitoring of beach topography and its change using unmanned aerial vehicle imagery, Ocean Coast. Manag., 160(April), 103-116, doi:10.1016/j.ocecoaman.2018.04.007, 2018.

Choi, K. Y. and Cheung, R. W. M.: Landslide disaster prevention and mitigation through works in Hong Kong, J. Rock Mech. Geotech. Eng., 5(5), 354-365, doi:10.1016/j.jrmge.2013.07.007, 2013.

Cruden, D. M. and Varnes, D. J.: Landslides: investigation and mitigation. Chapter 3-Landslide types and processes, Spec. Rep., 247(August), 36-75, doi:10.1007/s10346-009-0175-2, 1996.

510 Dewitte, O., Jasselette, J. C., Cornet, Y., Van Den Eeckhaut, M., Collignon, A., Poesen, J. and Demoulin, A.: Tracking landslide displacements by multi-temporal DTMs: A combined aerial stereophotogrammetric and LIDAR approach in western Belgium, Eng. Geol., 99(1-2), 11-22, doi:10.1016/j.enggeo.2008.02.006, 2008.

Donnini, M., Napolitano, E., Salvati, P., Ardizzone, F., Bucci, F., Fiorucci, F., Santangelo, M., Cardinali, M. and Guzzetti, F.: Impact of event landslides on road networks: a statistical analysis of two Italian case studies, Landslides, 14(4), 1521-1535, doi:10.1007/s10346-017-0829-4, 2017.

Eltner, A., Kaiser, A., Castillo, C., Rock, G., Neugirg, F. and Abellán, A.: Image-based surface reconstruction in geomorphometry-merits, limits and developments, Earth Surf. Dyn., 4(2), 359-389, doi:10.5194/esurf-4-359-2016, 2016. 
https://doi.org/10.5194/nhess-2021-32

Preprint. Discussion started: 8 February 2021

(C) Author(s) 2021. CC BY 4.0 License.

Fernández, T., Jiménez, J., Delgado, J., Cardenal, J., Pérez, J. L., Hamdouni, R. El and Irigaray, C.: Methodology for Landslide Susceptibility and Hazard Mapping Using GIS and SDI, Intell. Syst. Cris. Manag., 185-198, doi:10.1007/978-3-642-33218$0,2013$.

Fernández, T., Pérez, J. L., López, A., Gómez, J. M., Cardenal, J. and Delgado, J.: Monitorización de laderas inestables mediante técnicas fotogramétricas a partir de vuelos UAV e históricos, 2014.

Fernández, T., Pérez, J. L., Cardenal, F. J., López, A., Gómez, J. M., Colomo, C., Delgadoa, J. and Sánchez, M.: Use of a light UAV and photogrammetric techniques to study the evolution of a landslide in Jaén (Southern Spain), Int. Arch. Photogramm.

Remote Sens. Spat. Inf. Sci. - ISPRS Arch., 40(3W3), 241-248, doi:10.5194/isprsarchives-XL-3-W3-241-2015, 2015.

Fernández, T., Pérez, J. L., Cardenal, J., Gómez, J. M., Colomo, C. and Delgado, J.: Analysis of landslide evolution affecting olive groves using UAV and photogrammetric techniques, Remote Sens., 8(10), doi:10.3390/rs8100837, 2016.

Fernández, T., Pérez, J., Colomo, C., Cardenal, J., Delgado, J., Palenzuela, J., Irigaray, C. and Chacón, J.: Assessment of the Evolution of a Landslide Using Digital Photogrammetry and LiDAR Techniques in the Alpujarras Region (Granada, Southeastern Spain), Geosciences, 7(2), 32, doi:10.3390/geosciences7020032, 2017.

Gaprindashvili, G. and Van Westen, C. J.: Generation of a national landslide hazard and risk map for the country of Georgia, Nat. Hazards, 80(1), 69-101, doi:10.1007/s11069-015-1958-5, 2016.

González-Aguilera, D., López-Fernández, L., Rodriguez-Gonzalvez, P., Guerrero, D., Hernandez-Lopez, D., Remondino, F., Menna, F., Nocerino, E., Toschi, I., Ballabeni, A. and Gaiani, M.: Development of an all-purpose free photogrammetric tool, Int. Arch. Photogramm. Remote Sens. Spat. Inf. Sci. - ISPRS Arch., 41(September), 31-38, doi:10.5194/isprsarchives-XLIB6-31-2016, 2016.

Hackney, C. and Clayton, A. I.: Unmanned Aerial Vehicles (UAVs) and their application in geomorphic mapping, Geomorphol. Tech., 7, 1-12 fonline] Available http://www.geomorphology.org.uk/sites/default/files/geom_tech_chapters/2.1.7_UAV.pdf, 2015.

540 Hastaoglu, K. O. and Sanli, D. U.: Accuracy of GPS Rapid Static Positioning: Application to Koyulhisar Landslide, Central Turkey, Surv. Rev., 43(321), 226-240, doi:10.1179/003962611X12894696205145, 2011.

Hsieh, Y. C., Chan, Y. C. and Hu, J. C.: Digital elevation model differencing and error estimation from multiple sources: A case study from the Meiyuan Shan landslide in Taiwan, Remote Sens., 8(3), doi:10.3390/rs8030199, 2016.

Hungerbühler, D., Steinmann, M., Winkler, W., Seward, D., Egüez, A., Peterson, D. E., Helg, U. and Hammer, C.: Neogene 
https://doi.org/10.5194/nhess-2021-32

Preprint. Discussion started: 8 February 2021

(C) Author(s) 2021. CC BY 4.0 License.

Hungr, O., Leroueil, S. and Picarelli, L.: The Varnes classification of landslide types, an update, Landslides, 11(2), 167-194, doi:10.1007/s10346-013-0436-y, 2014.

Irigaray, C. and Palenzuela, J. A.: Análisis de la actividad de movimientos de ladera mediante láser escáner terrestre en el suroeste de la Cordillera Bética (España) Landslide activity analysis using terrestrial laser scanning at southwest of the Betic Cordillera (Spain) Copia personal, , 31(October 2014), 53-67, 2013.

Jaboyedoff, M., Oppikofer, T., Abellán, A., Derron, M. H., Loye, A., Metzger, R. and Pedrazzini, A.: Use of LIDAR in landslide investigations: A review, Nat. Hazards, 61(1), 5-28, doi:10.1007/s11069-010-9634-2, 2012.

Johnson, K., Nissen, E., Saripalli, S., Arrowsmith, J. R., McGarey, P., Scharer, K., Williams, P. and Blisniuk, K.: Rapid mapping of ultrafine fault zone topography with structure from motion, Geosphere, 10(5), 969-986, doi:10.1130/GES01017.1, 2014.

Kasai, M., Ikeda, M., Asahina, T. and Fujisawa, K.: LiDAR-derived DEM evaluation of deep-seated landslides in a steep and rocky region of Japan, Geomorphology, 113(1-2), 57-69, doi:10.1016/j.geomorph.2009.06.004, 2009.

Kasperski, J., Delacourt, C., Allemand, P., Potherat, P., Jaud, M. and Varrel, E.: Application of a Terrestrial Laser Scanner 560 (TLS) to the study of the Séchilienne landslide (Isère, France), Remote Sens., 2(12), 2785-2802, doi:10.3390/rs122785, 2010. Kiseleva, E., Mikhailov, V., Smolyaninova, E., Dmitriev, P., Golubev, V., Timoshkina, E., Hooper, A., Samiei-Esfahany, S. and Hanssen, R.: PS-InSAR Monitoring of Landslide Activity in the Black Sea Coast of the Caucasus, Procedia Technol., 16(October 2015), 404-413, doi:10.1016/j.protcy.2014.10.106, 2014.

Kršák, B., Blišt’an, P., Pauliková, A., Puškárová, P., Kovanič, L., Palková, J. and Zelizňaková, V.: Use of low-cost UAV photogrammetry to analyze the accuracy of a digital elevation model in a case study, Meas. J. Int. Meas. Confed., 91, 276287, doi:10.1016/j.measurement.2016.05.028, 2016.

Kumar, R. and Anbalagan, R.: Landslide susceptibility zonation of Tehri reservoir rim region using binary logistic regression model Landslide susceptibility zonation of Tehri reservoir rim region using binary logistic regression model, , 108(9), 2015.

Lari, S., Frattini, P. and Crosta, G. B.: A probabilistic approach for landslide hazard analysis, Eng. Geol., 182(PA), 3-14, doi:10.1016/j.enggeo.2014.07.015, 2014.

Li, W. and Wang, C.: GPS in the tailings dam deformation monitoring, Procedia Eng., 26, 1648-1657, doi:10.1016/j.proeng.2011.11.2350, 2011.

Lindner, G., Schraml, K., Mansberger, R. and Hübl, J.: UAV monitoring and documentation of a large landslide, Appl. Geomatics, 8(1), 1-11, doi:10.1007/s12518-015-0165-0, 2016. 
https://doi.org/10.5194/nhess-2021-32

Preprint. Discussion started: 8 February 2021

(c) Author(s) 2021. CC BY 4.0 License.

Malet, J., Ferhat, G., Ulrich, P. and Boetzlé, P.: The French National Landslide Observatory OMIV - Monitoring surface displacement using permanent GNSS, photogrammetric cameras and terrestrial LiDAR for understanding the landslide mechanisms, (1), 1-7, 1994.

McKean, J. and Roering, J.: Objective landslide detection and surface morphology mapping using high-resolution airborne laser altimetry, Geomorphology, 57(3-4), 331-351, doi:10.1016/S0169-555X(03)00164-8, 2004.

580 Medjkane, M., Maquaire, O., Costa, S., Roulland, T., Letortu, P., Fauchard, C., Antoine, R. and Davidson, R.: High-resolution monitoring of complex coastal morphology changes: cross-efficiency of SfM and TLS-based survey (Vaches-Noires cliffs, Normandy, France), Landslides, 15(6), 1097-1108, doi:10.1007/s10346-017-0942-4, 2018.

Metternicht, G., Hurni, L. and Gogu, R.: Remote sensing of landslides: An analysis of the potential contribution to geo-spatial systems for hazard assessment in mountainous environments, Remote Sens. Environ., 98(2-3), 284-303, 585 doi:10.1016/j.rse.2005.08.004, 2005.

Mirzaee, S., Motagh, M. and Akbari, B.: Landslide monitoring using insar time-series and GPS observations, case study: Shabkola landslide in northern Iran, Int. Arch. Photogramm. Remote Sens. Spat. Inf. Sci. - ISPRS Arch., 42(1W1), 487-492, doi:10.5194/isprs-archives-XLII-1-W1-487-2017, 2017.

Mozas-Calvache, A. T., Pérez-García, J. L., Cardenal-Escarcena, F. J., Mata-Castro, E. and Delgado-García, J.: Method for photogrammetric surveying of archaeological sites with light aerial platforms, J. Archaeol. Sci., 39(2), 521-530, doi:10.1016/j.jas.2011.10.007, 2012.

Mozas-Calvache, A. T., Pérez-García, J. L., Fernández, T., Gómez-López, J. M. and Colomo-Jiménez, C.: Analysis of Landslides Based on Displacements of Lines, ISPRS - Int. Arch. Photogramm. Remote Sens. Spat. Inf. Sci., XLI-B7(July), 549-555, doi:10.5194/isprsarchives-XLI-B7-549-2016, 2016.

595 Mozas-Calvache, A. T., Pérez-García, J. L. and Fernández, T.: Monitoring of landslide displacements using UAS and control methods based on lines, Landslides, (May), 1-14, doi:10.1007/s10346-017-0842-7, 2017.

Niethammer, U., Rothmund, S., Schwaderer, U., Zeman, J. and Joswig, M.: Open Source Image-Processing Tools for LowCost Uav-Based Landslide Investigations, ISPRS - Int. Arch. Photogramm. Remote Sens. Spat. Inf. Sci., XXXVIII-1/(February 2016), 161-166, doi:10.5194/isprsarchives-XXXVIII-1-C22-161-2011, 2012.

600 Peppa, M. V., Mills, J. P., Moore, P., Miller, P. E. and Chambers, J. E.: Accuracy assessment of a uav-based landslide monitoring system, Int. Arch. Photogramm. Remote Sens. Spat. Inf. Sci. - ISPRS Arch., 41, 895-902, doi:10.5194/isprsarchives-XLI-B5-895-2016, 2016a. 
https://doi.org/10.5194/nhess-2021-32

Preprint. Discussion started: 8 February 2021

(C) Author(s) 2021. CC BY 4.0 License.

Peppa, M. V., Mills, J. P., Moore, P., Miller, P. E. and Chambers, J. E.: Accuracy assessment of a uav-based landslide monitoring system, Int. Arch. Photogramm. Remote Sens. Spat. Inf. Sci. - ISPRS Arch., 41(July), 895-902, doi:10.5194/isprsarchives-XLI-B5-895-2016, 2016 b.

Peppa, M. V., Mills, J. P., Moore, P., Miller, P. E. and Chambers, J. E.: Automated co-registration and calibration in SfM photogrammetry for landslide change detection, Earth Surf. Process. Landforms, 44(1), 287-303, doi:10.1002/esp.4502, 2019.

Pesci, A., Teza, G., Casula, G., Fabris, M. and Bonforte, A.: Remote sensing and geodetic measurements for volcanic slope monitoring: Surface variations measured at Northern Flank of La Fossa cone (Vulcano Island, Italy), Remote Sens., 5(5), 2238-2256, doi:10.3390/rs5052238, 2013.

Peternel, T., Kumelj, Š., Oštir, K. and Komac, M.: Monitoring the Potoška planina landslide (NW Slovenia) using UAV photogrammetry and tachymetric measurements, Landslides, 14(1), 395-406, doi:10.1007/s10346-016-0759-6, 2017.

Pix4D, G.: User Manual Pix4Dmapper 4.1, 305p. [online] Available from: www.pix4D.com, 2017.

Ponomarev, A. A., Zerkal, O. V. and Samarin, E. N.: Protection of the Transport Infrastructure from Influence of Landslides by Suspension Grouting, Procedia Eng., 189(May), 880-885, doi:10.1016/j.proeng.2017.05.137, 2017.

Prokešová, R., Kardoš, M. and Medved'ová, A.: Landslide dynamics from high-resolution aerial photographs: A case study from the Western Carpathians, Slovakia, Geomorphology, 115(1-2), 90-101, doi:10.1016/j.geomorph.2009.09.033, 2010.

Psimoulis, P. A., Houlié, N., Habboub, M., Michel, C. and Rothacher, M.: Detection of ground motions using high-rate GPS time-series, Geophys. J. Int., 214(2), 1237-1251, doi:10.1093/gji/ggy198, 2018.

620 Rawat, M. S., Joshi, V., Rawat, B. S. and Kumar, K.: Landslide movement monitoring using GPS technology: A case study of Bakthang landslide, Gangtok , East Sikkim , India, J. Dev. Agric. Econ., 3(May), 194-200, 2011.

Roque, D., Fonseca, A. M., Henriques, M. J. and Falcão, A. P.: A First Approach for Displacement Analysis in Lisbon Downtown Using PS-InSAR, Procedia Technol., 16, 288-293, doi:10.1016/j.protcy.2014.10.094, 2014.

Rossi, G., Tanteri, L., Tofani, V., Vannocci, P., Moretti, S. and Casagli, N.: Multitemporal UAV surveys for landslide mapping and characterization, Landslides, (November 2017), 1-8, doi:10.1007/s10346-018-0978-0, 2018.

Růžičková, K. and Inspektor, T.: Surface models for geosciences., 2015.

Seitz, S. M., Curless, B., Diebel, J., Scharstein, D. and Szeliski, R.: A comparison and evaluation of multi-view stereo reconstruction algorithms, Proc. IEEE Comput. Soc. Conf. Comput. Vis. Pattern Recognit., 1, 519-526, doi:10.1109/CVPR.2006.19, 2006. 
https://doi.org/10.5194/nhess-2021-32

Preprint. Discussion started: 8 February 2021

(C) Author(s) 2021. CC BY 4.0 License.

630 Singleton, A., Li, Z., Hoey, T. and Muller, J. P.: Evaluating sub-pixel offset techniques as an alternative to D-InSAR for monitoring episodic landslide movements in vegetated terrain, Remote Sens. Environ., 147, 133-144, doi:10.1016/j.rse.2014.03.003, 2014.

Soto, J., Galve, J. P., Palenzuela, J. A., Azañón, J. M., Tamay, J. and Irigaray, C.: A multi-method approach for the characterization of landslides in an intramontane basin in the Andes (Loja, Ecuador), Landslides, (March), 1-19, doi:10.1007/s10346-017-0830-y, 2017.

Stumpf, A., Malet, J. P., Kerle, N., Niethammer, U. and Rothmund, S.: Image-based mapping of surface fissures for the investigation of landslide dynamics, Geomorphology, 186, 12-27, doi:10.1016/j.geomorph.2012.12.010, 2013.

Stumpf, A., Malet, J. P., Allemand, P., Pierrot-Deseilligny, M. and Skupinski, G.: Ground-based multi-view photogrammetry for the monitoring of landslide deformation and erosion, Geomorphology, 231, 130-145,

640 doi:10.1016/j.geomorph.2014.10.039, 2015.

Tiwari, A., Narayan, A. B., Devara, M., Dwivedi, R., Dikshit, O., Assessment, D., Reduction, R., Navigation, G. and Total, R.: Multi-Sensor Geodetic Approach for Landslide Detection and, IV(November), 20-23, doi:10.5194/isprs-annals-IV-5-287$2018,2018$.

Turner, D., Lucieer, A. and de Jong, S. M.: Time series analysis of landslide dynamics using an Unmanned Aerial Vehicle (UAV), Remote Sens., 7(2), 1736-1757, doi:10.3390/rs70201736, 2015.

Uysal, M., Toprak, A. S. and Polat, N.: DEM generation with UAV Photogrammetry and accuracy analysis in Sahitler hill, Meas. J. Int. Meas. Confed., 73, 539-543, doi:10.1016/j.measurement.2015.06.010, 2015.

Vrublová, D., Kapica, R., Jiránková, E. and Struś, A.: Documentation od landslides and inaccessible parts of a mine using a unmanned UAV system and methods of digital terrestrial photogrammetry., , LXI(3), 8-19, doi:10.1515/gse-2015-0018, 2015.

650 Walstra, J. and Chandler, J. H.: Time for change-quantifying landslide evolution using historical aerial photographs and modern photogrammetric methods, Int. Soc. Photogramm. Remote Sens. Spat. Inf. Scienes, 35, 475-480 [online] Available from: http://www.cartesia.org/geodoc/isprs2004/comm4/papers/395.pdf, 2004.

Wang, G. Q.: Millimeter-accuracy GPS landslide monitoring using Precise Point Positioning with Single Receiver Phase Ambiguity (PPP-SRPA) resolution: a case study in Puerto Rico, J. Geod. Sci., 3(1), 22-31, doi:10.2478/jogs-2013-0001, 2013.

655 Warrick, J. A., Ritchie, A. C., Schmidt, K. M., Reid, M. E. and Logan, J.: Characterizing the catastrophic 2017 Mud Creek landslide, California, using repeat structure-from-motion (SfM) photogrammetry, Landslides, (February), doi:10.1007/s10346-019-01160-4, 2019.

Wheaton, J. M., Brasington, J., Darby, S. E. and Sear, D. A.: Accounting for uncertainty in DEMs from repeat topographic surveys: Improved sediment budgets, Earth Surf. Process. Landforms, 35(2), 136-156, doi:10.1002/esp.1886, 2010. 
https://doi.org/10.5194/nhess-2021-32

Preprint. Discussion started: 8 February 2021

(C) Author(s) 2021. CC BY 4.0 License.

(c) (1)

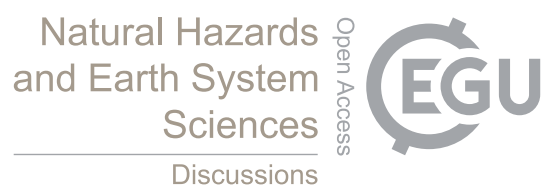

660 WP/WLI: Describing landslides in several languages; the Multilingual Landslide Glossary, , 59, 1993.

Yucel, M. A. and Turan, R. Y.: Areal Change Detection and 3D Modeling of Mine Lakes Using High-Resolution Unmanned Aerial Vehicle Images, Arab. J. Sci. Eng., 41(12), 4867-4878, doi:10.1007/s13369-016-2182-7, 2016.

Zárate, B.: Monitoreo de movimientos de ladera en el sector de San Pedro de Vilcabamba mediante procedimientos GPS, Maskana, 2(2), 17-25, doi:/10.18537/mskn.02.02.02, 2011. 